\title{
The genus Cymbopleura (Cymbellales, Bacillariophyta) from high altitude freshwater habitats, Everest National Park, Nepal, with the description of two new species.
}

\author{
Bart Van de Vijver ${ }^{*}$, Ingrid Jüttner ${ }^{2}$, Smriti Gurung ${ }^{3}$, Chhatra Sharma ${ }^{3}$, \\ Subodh Sharma ${ }^{3}$, Myriam de HaAn $^{1} \&$ Eileen J. Cox ${ }^{4}$ \\ ${ }^{1}$ National Botanic Garden, Department of Bryophyta \& Thallophyta, Domein van Bouchout, B-1860 Meise, \\ Belgium; *corresponding author e-mail: vandevijver@brfgov.be \\ ${ }^{2}$ National Museum Wales, Department of Biodiversity and Systematic Biology, Cathays Park, Cardiff, CF10 3NP, \\ United Kingdom \\ ${ }^{3}$ Kathmandu University, Department of Environmental Science and Engineering, Aquatic Ecology Centre, P.O. \\ Box 6250, Kathmandu, Nepal \\ ${ }^{4}$ Department of Botany, The Natural History Museum, Cromwell Road, London, SW7 5BD, United Kingdom
}

\begin{abstract}
As part of a study on the diatom flora of the Gokyo Valley, Everest National Park, Nepal, eleven species of Cymbopleura (Bacillariophyta), including two new species, Cymbopleura gokyoensis JüTTNER et VAN DE VIJVER sp. nov. and Cymbopleura emoda JÜTTNER et VAN DE VIJVER sp. nov., were investigated using light and electron microscopy. Some taxa could not be identified with certainty using the currently available literature due to small differences in valve dimensions, raphe structure and striation patterns. It remains unclear whether they represent new species or whether the original descriptions should be emended to include the populations from Nepal.
\end{abstract}

Key words: algae, Asia, Bacillariophyta, Cymbopleura, Gokyo, Himalaya, morphology, Nepal, new species

\section{Introduction}

Krammer (1982a) established Cymbopleura as a subgenus of Cymbella C.AGARDH, distinguished somewhat negatively as containing all former Cymbella species that did not belong in Cymbella sensu stricto C.AGARDH 1830 or Cymbella subgenus Encyonema (KÜTz.) KRAMmer. Cymbella subgenus Cymbopleura initially contained several taxa that have subsequently been transferred to the genus Encyonopsis (Krammer 1982a, 1997), such as Cymbella (Cymbopleura) cesatii GRUNow. In 1997, KRAMMER invalidly raised the subgenus to generic level, invalid because he failed to cite a basionym. KRAMMER later (1999) corrected this and more recently (KRAMMER 2003) reviewed many Cymbopleura species, describing 51 new species and 36 new varieties, and transferring 70 former Cymbella taxa to Cymbopleura. Since then, several new taxa have been described for this genus, for example by LevKov et al. (2007), Metzeltin \& Lange-Bertalot (2007) and
Metzeltin et al. (2009).

As in Cymbella, in Cymbopleura the external distal raphe endings are dorsally deflected and the proximal raphe endings are often ventrally deflected. On the other hand, unlike Cymbella, Cymbopleura spp. lack stigmata and apical pore fields, and many species have only slightly asymmetrical valves. The valve outline is often similar in Cymbopleura and Encyonopsis but the latter has ventrally deflected external distal raphe endings and the proximal raphe endings are (sometimes) dorsally deflected.

High altitude freshwaters and terrestrial habitats of the Everest National Park, Nepal, support a diverse diatom flora (at both species and generic levels), including several new, and rarely found, cymbelloid taxa [Oricymba (JüTTNER et al.2010a), Cymbopleura, Cymbella (JÜTTNER et al.2010b), Encyonema and Encyonopsis], some of which have unusual morphological features for their respective genera. In the present paper, we present an account of the Cymbopleura species 
from terrestrial habitats and springs in the Gokyo area observed in this study. Two new species, Cymbopleura gokyoensis JÜTTNER et VAN DE VIJVER sp. nov. and Cymbopleura emoda JÜTTNER et VAN DE VIJVER sp. nov., are formally described. The morphology of the genus is discussed, focussing on several rare features, such as the pore arrangement around the apices and the presence of what Krammer (1982a, 2003) called 'papillae', features omitted from the original diagnosis of Cymbopleura.

\section{Material and Methods}

Study area. In October 2008 and May 2009, diatoms were collected at the lake margin of the $3^{\text {rd }}$ lake (Dudh
Pokhari or Gokyo Lake), its inlets and surroundings in the Gokyo Valley, Everest (Sagarmatha) National Park, Nepal, between ca. $4750-4800 \mathrm{~m}$ a.s.l. (Fig. $1)$. The main inlet of the $3^{\text {rd }}$ lake lies at its northern margin and a second inlet is located at the western side of the lake. The springs are located on the southern slope of the mountain Gokyo Ri, about $50 \mathrm{~m}$ above the northern lake margin. Samples were taken from aerial and submerged habitats, including damp areas and vegetation, on available substrata from stream, spring and lake margins, such as bryophytes, filamentous algae, rock, sand, sediment and soil.

Laboratory procedures. Diatom samples were processed using hot $\mathrm{H}_{2} \mathrm{O}_{2}$ oxidation. Cleaned diatom valves were mounted in Naphrax ${ }^{\circledR}$. Light microscope observations were conducted using an Olympus BX51 microscope and a Nikon E600 microscope, equipped

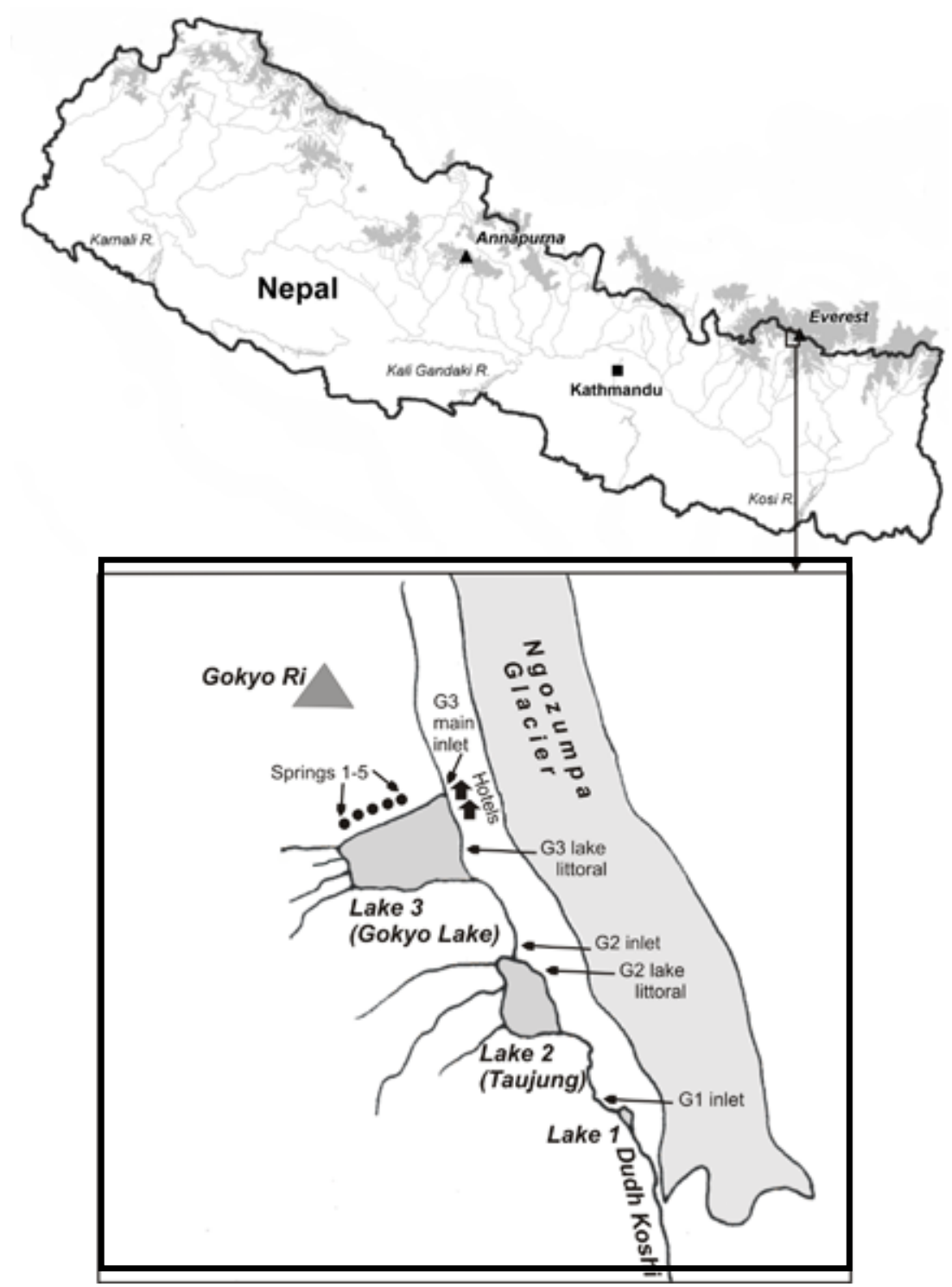

Fig. 1. Map of the study area. 
with Differential Interference Contrast (Nomarski, $\mathrm{x} 1000$, oil immersion). Stria densities have been determined by counting striae in $10 \mu \mathrm{m}$, from the central raphe ending towards the valve apex. For scanning electron microscopy (SEM), part of the suspension was filtered through polycarbonate membrane filters with a pore diameter of $3 \mu \mathrm{m}$, pieces of which were fixed on aluminium stubs after air-drying. The stubs were sputter-coated with $50 \mathrm{~nm}$ of gold and studied in a JEOL-5800LV at $20 \mathrm{kV}$.

Holotype slides and cleaned samples are held at the National Museum of Wales (Cardiff, U.K.), and isotype slides at the National Botanic Garden of Belgium (Meise, Belgium), at Kathmandu University (Dhulikhel, Nepal), in the Hustedt Collection of the Alfred-Wegener-Institut für Polar- und Meeresforschung (Bremerhaven, Germany) and in The Natural History Museum (London, U.K.).

Note on terminology. In his various works on cymbelloid diatoms, KrAmmer (1982a, b, 1997a, b, 2002, 2003) used terminology for parts of the diatom valve which do not correspond to that used by other workers (Ross et al. 1979, Cox \& Ross 1981, MANN 1981b, Cox 2004). In particular, he (KRAMMER 1982b) describes the internal valve structure as having alveoli separated by costae, despite the fact that alveolus refers to chambered striae in genera such as Pinnularia, and costa being restricted to secondarily thickened structures (Ross et al. 1979). We follow the stria terminology suggested by Cox \& Ross (1981), whereby the first formed ribs that will define striae are termed virgae, and the cross connections, vimines. Similarly, although KrAmMER (1982a, b, 1997a, b, 2002, 2003) used the term puncta (dot) for a pore within a stria, we will use the English word pore, because this better describes the structure.

The distinction between raphe systems having and lacking an intermissio is also problematic. All cymbelloid diatoms have an internal interruption between the two raphe slits, but in some there is an overgrowth of silica that hides the deflected endings, i.e. "lacking an intermissio" (cf. Cox 1999). In mature valves this overgrowth will have a smooth edge, but occasionally, if silicification is not complete, a small break will be visible at the middle, reminiscent of an "intermissio", and thus liable to misinterpretation.

\section{Observations}

Eleven Cymbopleura taxa (including species and varieties) were found in freshwater and terrestrial habitats of the area around the $3^{\text {rd }}$ lake in the Gokyo Valley, including two species new to science, Cymbopleura gokyoensis JÜTTNER et VAN DE VIJVER sp. nov. and $C$. emoda JÜTTNER et VAN
DE ViJver sp. nov. Table 1 lists all Cymbopleura occurrences in the investigated samples. The most common taxa were Cymbopleura oblongata var. parva KRAMMER, Cymbopleura cf. mongolica Metzeltin, Lange-Bert. et Nergui and $C$. gokyoensis, which occurred at 14, 18 and 12 sites, respectively. Cymbopleura $\mathrm{cf}$. gondwana LANGEBert., Krammer et Rumrich, $C$. naviculiformis (Auersw.) Krammer, $C$. cf. venetaeformis P.B. Hamilton et D. Antoniades and $C$. emoda occurred at 4-7 sites. Cymbopleura anglica (Lagerst.) Krammer, $C$. cf. linearis (Foged) Krammer, $C$. americana (A. Schmidt) Krammer and $C$. nadejdae Metzeltin, Lange-Bert. et NERGUI were present at 1-3 sites and, apart from $C$. americana and one valve of C. anglica, were so rare that they could not be studied with SEM.

\section{Cymbopleura americana (A. SCHMIDT) KRAMMER \\ LM morphology (Figs 2-6). Valves dorsiventral} with apiculate apices, strongly convex dorsal margins and convex ventral margins, which may be almost straight near the valve centre. Valve dimensions ( $\mathrm{n}=15)$ : length 54-78 $\mu \mathrm{m}$, width $20.1-$ $21.7 \mu \mathrm{m}$, length/width ratio 2.7-3.7. Axial area lanceolate, c. $4 \mu \mathrm{m}$ wide near the valve centre. Central area rounded, slightly asymmetrical and larger on the ventral side, less than half the valve width. Raphe clearly lateral and very slightly ventrally curved near the valve centre, proximal raphe endings deflected towards the ventral side. Striae radiate throughout the entire valve, $9-10$ in $10 \mu \mathrm{m}$ dorsally, $11-12$ in $10 \mu \mathrm{m}$ ventrally. Pores clearly discernible, 20-24 in $10 \mu \mathrm{m}$.

SEM morphology (Figs 7-12). Externally, proximal raphe endings expanded forming a hook (Figs 7, 8). Distal raphe endings deflected dorsally, slightly bayonet-shaped, terminating in an area of irregularly arranged, small rounded pores, with a small hyaline area on the ventral side of the raphe slit (Fig. 9). Areola openings apically elongated slits, sometimes irregularly positioned, forming uniseriate striae, ca. 25 in $10 \mu \mathrm{m}$ (Figs 8 , 9). Internally, broad virgae present separating the striae subdivided by narrow vimines, areola openings without internal occlusions (Figs 10-12). Raphe slit with internal central endings on the dorsal side of the asymmetrical central nodule, ending near the apices in small, knob-like helictoglossae (Figs 11, 12). 
Table 1. Occurences of Cymbopleura species at sites in the Gokyo Valley, Everest National Park, Nepal [(VA) very abundant;(A) abundant; (X) present; (VR) very rare)].

NMW.C.2009.003.32 G3 spring 1 sediment

NMW.C.2009.003.52 G3 spring 1 rock

NMW.C.2009.003.G3 spring 1 bryophytes

NMW.C.2009.003.G3 spring 2 exposed bryophytes

NMW.C.2009.003.30 G3 spring 2 rocks

NMW.C.2009.003.40 G3 spring 2 near bridge sand

NMW.C.2009.003.50 G3 spring 2 sediment

NMW.C.2009.003. G3 spring 3 exposed bryophytes

NMW.C.2009.003.45 G3 spring 3 filamentous algae

NMW.C.2009.003.31 G3 spring 3 sand

NMW.C.2009.003.44 G3 spring 3 sediment

NMW.C.2009.003. G3 spring 4 bryophytes

NMW.C.2009.003.G3 spring 4 exposed bryophytes

NMW.C.2009.003.41 G3 spring 4 filamentous algae

NMW.C.2009.003.47 G3 spring 4 sand

NMW.C.2009.003.35 G3 spring 4 sediment

NMW.C.2009.003.38 G3 spring 5 sediment

NMW.C.2009.003.147 G3 spring bryophyte

NMW.C.2009.003.146 G3 spring rock

NMW.C.2009.003.149 G3 spring submerged sand

NMW.C.2009.003.148 G3 spring brown sediment

NMW.C.2009.003.18 G3 lake littoral near main inlet sand

NMW.C.2009.003.G3 inlet north slope exposed brown sand

NMW.C.2009.003.G3 inlet north slope exposed sand NMW.C.2009.003.G3-3 main inlet exposed moist soil

NMW.C.2009.003.G3-3 main inlet puddle near stream exposed soil

NMW.C.2009.003.G3 inlet 2 exposed macrophytes NMW.C.2009.003.G3 near inlet 2 exposed red sediment

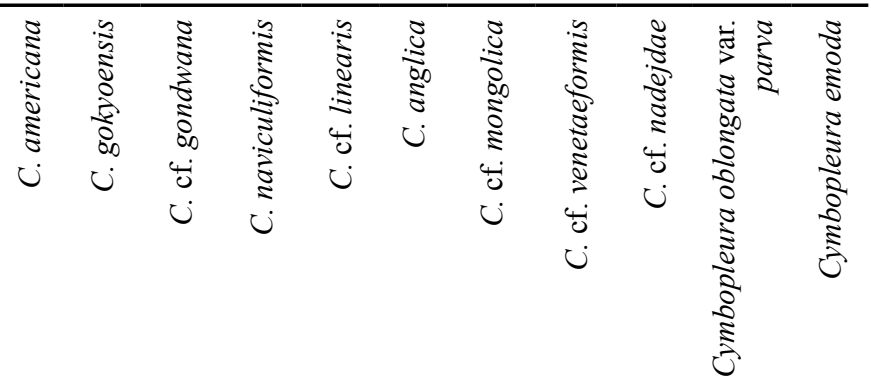

VR

VR

VR VR

VR

VR VR

VR

VR

$\mathrm{X}$

VR

VR

$\mathrm{X}$

VR

VR

VR

VR

VR

VR

X

VR X

VR VR

VR

VR

VR VR

VR VR

VR VR

VR VR

VR $\quad \mathrm{X} \quad \mathrm{VR}$

VR VR VR

X VR

$\mathrm{X}$

$\begin{array}{lllll}\text { VA A VR } & \text { VR }\end{array}$

$\begin{array}{llllllll}\text { A } & \mathrm{X} & \text { VR } & \mathrm{X} & \mathrm{VR} & \mathrm{VR} & \mathrm{X}\end{array}$

X X

X VA $\quad \mathrm{X}$

VR VA A

$\begin{array}{lllll}\text { X } & \text { VR } & \text { X } & \text { VR } & \text { VR }\end{array}$

$\mathrm{X}$

VR

VR 

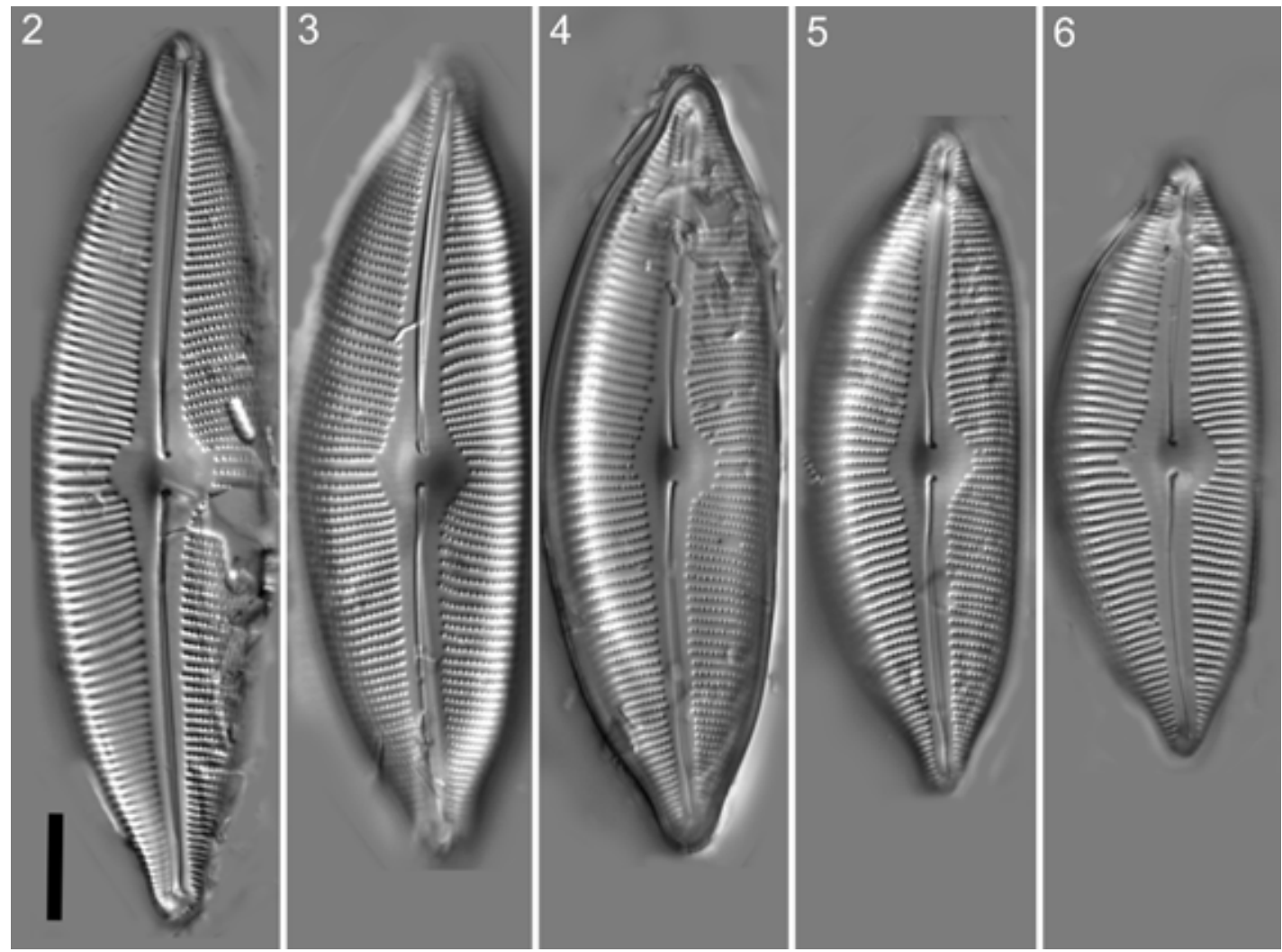

Figs 2-6. Cymbopleura americana, LM: slide NMW.C.2009.003 G3-3 main inlet puddle near stream, exposed soil. Valve views. Scale bar $10 \mu \mathrm{m}$.

Taxonomical remarks. The Himalayan species conforms to one of the drawings (i.e. fig. 15) of Cymbella americana A. SCHMIDT (SCHMIDT 1875, pl. 9 , figs 15, 20). This species was described from North Providence (presumably the town of North Providence, Rhode Island, United States). The specimen shown in the line drawing is $82 \mu \mathrm{m}$ long and $22 \mu \mathrm{m}$ wide, with 9 dorsal striae in $10 \mu \mathrm{m}$, and 10 ventral in $10 \mu \mathrm{m}$, increasing up to 14 in $10 \mu \mathrm{m}$ at the apices. According to KRAMMER (2003), who made the combination in the legend accompanying his reproductions of Schmidt's illustrations, type slides are not available. Although this transfer does not entirely conform to the International Code on Botanical Nomenclature (McNeILl et al. 2007, art. 33.5), giving the date of the publication (1874-1959) but lacking a formal indication of the original year of publication (1885), COMPÈRE (pers.comm.) regards the transfer as valid.

Cymbopleura americana is not identical with a number of other specimens identified as Cymbella americana. For example, KRASSKE (1949) subsumed Cymbella americana under Cymbella ehrenbergii var. americana (A.SCHMIDT) BOYER, a combination made by BOYER in 1927, who considered that $C$. americana only warranted varietal status within $C$. ehrenbergii. PAtRICK \& ReIMER (1975) included C. americana under Cymbella heteropleura var. subrostrata CLEVE, giving valve dimensions of 135-270 $\mu \mathrm{m}$ (length) and 37-52 $\mu \mathrm{m}$ (width), although CLEVE (1894) had suggested that, rather than being conspecific with C. heteropleura, C. americana (SснміDт 1875, pl. 9, figs 15, 20) was intermediate between Cymbella cuspidata and $C$. heteropleura var. minor. KRAMMER (2003), who investigated the material of Cymbella heteropleura var. subrostrata from the type locality, transferred it to Cymbopleura subrostrata, citing dimensions of 160-270 $\mu \mathrm{m}$ (length) and of 43-52 $\mu \mathrm{m}$ (width). This clearly differs from the much smaller $C$. americana that we have found.

Cymbopleura acuta var. angusta KRAMMER (2003, pl. 52-54) known from tropical South America (Essequibo River, Guyana) has more pointed, narrower apices than C. americana, whose apices are broader and rounder. Cymbella acuta v. angusta is narrower $(15-19 \mu \mathrm{m}$ vs. $20.1-21.7$ $\mu \mathrm{m})$ and its axial area is also narrower than that of C. americana. The nominate form, Cymbopleura acuta, has a more convex ventral margin, more pointed apices, a symmetrical central area in most 

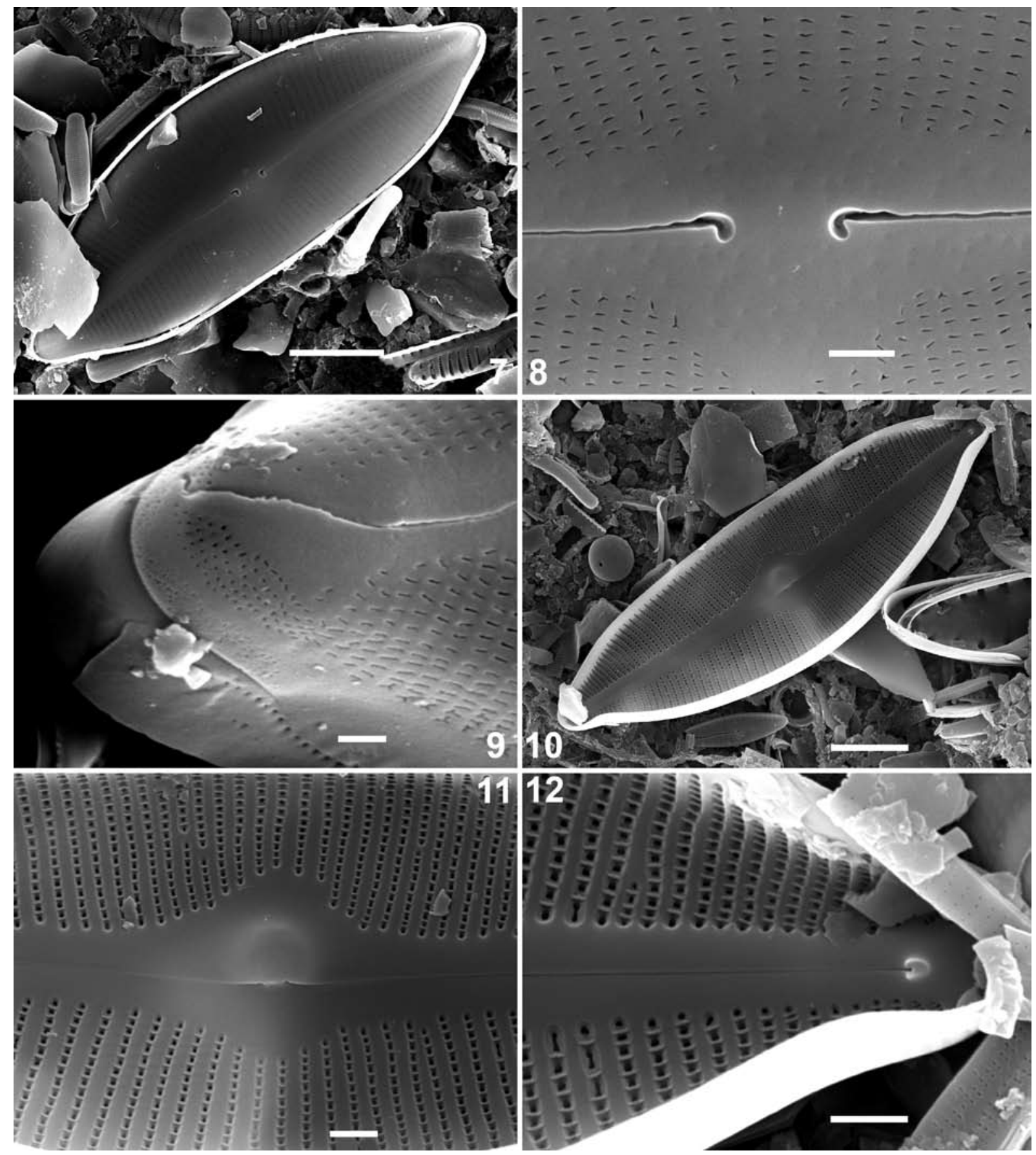

Figs 7-12. Cymbopleura americana, SEM: stub NMW.C.2009.003 G3-3 main inlet puddle near stream, exposed soil: (7-9) external views, (7) whole valve, (8) central area with ventrally deflected raphe endings, (9) apex with apical pore field and dorsally deflected raphe ending; (10-12) internal views, (10) whole valve, (11) valve centre with closely opposed central raphe endings and central nodule, (12) valve near apex with helictoglossa, virgae and narrow striae with struts over the vimines. Scales bar $10 \mu \mathrm{m}$ (Figs 7, 10); $2 \mu \mathrm{m}$ (Figs 8, 11, 12); $1 \mu \mathrm{m}$ (Fig. 9).

valves, and slightly more radiate, sometimes curved, striae.

Several other species also differ sufficiently from $C$. americana in valve shape, size, raphe, central and axial area characters not to be confused with it: i.e. Cymbopleura acutiformis KRAMMER has less protracted apices; $C$. brasiliana KRAMMER more symmetrical valves; $C$. apiculata Krammer,
C. subapiculata Krammer, C. cuspidata (KÜTZING) Krammer, C. subcuspidata (Krammer) Krammer and $C$. percuspidata KRAMMER, have rostrate apices and more symmetrical valves; $C$. lata (GRUNOw) Krammer and $C$. albanica Krammer \& Mino have very small central areas; and C. spuria (CLEVE) Krammer has less apiculate apices C. americana (see Krammer 2003). 


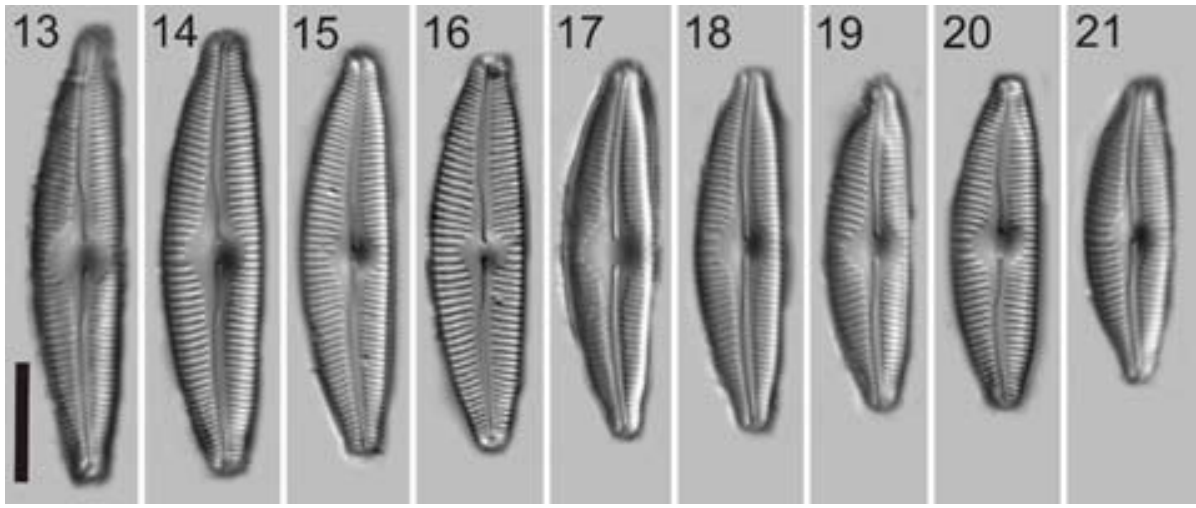

Figs 13-21. Cymbopleura gokyoensis, LM: (13, 15, 17-21) slide NMW.C.2009.003 G3-3 main inlet puddle near stream, exposed soil; $(14,16)$ slide NMW.C.2009.003 G3 spring 4, exposed bryophytes. Valve views. Scale bar $10 \mu \mathrm{m}$.

Ecology. Cymbopleura americana was only found on exposed, moist soil in a small puddle adjacent to the main inlet of the $3^{\text {rd }}$ lake, where it was rare (Table 1). Accompanying taxa included several species in the Achnanthidium minutissimum complex, Cymbopleura cf. venetaeformis, Brachysira brebisonii Ross, Cymbopleura oblongata var. parva, and several as yet unidentified araphid taxa, plus species of Gomphonema, Eunotia, Pinnularia and Aulacoseira.

Cymbopleura gokyoensis JÜTTNER \& VAN DE VIJVER, spec. nov. (Figs 13-27)

Diagnosis: Valvaedorsiventralesmarginibusdorsalibus moderate convexis marginibusque ventralibus leviter convexis apicibusque rostratis. Longitudo 27-49 $\mu \mathrm{m}$,

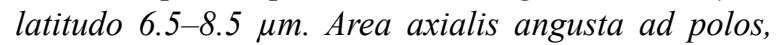
leviter dilatans admediam partem valvae. Area centralis symmetrica vel leviter asymmetrica, angustior in latere ventrali quam dorsali, 1/2-2/3 latitudinis valvae. Area centralis differt in duabus valvis frustulae eaedem. Raphe lateralis, leviter posita excentrice, ventraliter curvata ad centrum valvae. Striae radiatae, 15-17 in $10 \mu \mathrm{m}$ (dorsaliter) et 17-18 in $10 \mu \mathrm{m}$ (ventraliter). Puncta non discernenda in microscopio photonico, $35-40$ in $10 \mu \mathrm{m}$.

Holotypus: NMW.C.2009.003.G3-3 main inlet puddle near stream, exposed soil. National Museum of Wales, Cardiff, U.K. (NMW).

Isotypes: BR-4190, National Botanic Garden of Belgium, Meise, Belgium; Kathmandu University, Aquatic Ecology Centre, Dhulikhel, Nepal; BRM ZU7/94, Hustedt Collection, Alfred-WegenerInstitut für Polar- und Meeresforschung, Bremerhaven, Germany; BM 101481, The Natural History Museum, London, U.K.

Locus typicus: A small puddle with moist, exposed soil, adjacent to the main inlet of the $3^{\text {rd }}$ lake on its northern shore in the Gokyo Valley, Everest National Park, Nepal, at 4750 m a.s.l., (coll. S. Gurung 18.10.2008).

Etymology: The species was named after the Gokyo Valley, Nepal, where the type population was found.

LM morphology (Figs 13-21). Valves dorsiventral with rostrate apices, moderately convex dorsal margin and slightly convex ventral margin, which can be almost straight near the valve centre. Valve dimensions $(n=14)$ : length 27-49 $\mu \mathrm{m}$, width $6.5-8.5 \mu \mathrm{m}$, length/width ratio 3.5-5.4. Narrow, lanceolate axial area widening slightly towards the valve centre. Rhombic to almost circular central area extending $1 / 2-2 /{ }_{3}$ of the valve width, symmetrical or slightly asymmetrical with the smaller area on either the ventral or on the dorsal side. Central area sometimes differing in size and shape between the two valves of the same frustule. Raphe lateral, slightly eccentric, curved ventrally towards the valve centre, proximal raphe endings very slightly ventrally deflected. Striae radiate throughout the entire valve, 15-17 in 10 $\mu \mathrm{m}$ (dorsal), $17-18$ in $10 \mu \mathrm{m}$ (ventral). Pores not discernable.

SEM morphology (Figs 22-27). Externally, slightly widened proximal raphe endings, straight or slightly deflected towards the ventral side (Fig. 22). Distal raphe endings deflected to the dorsal side, terminating between shortened striae extending around the apices (Figs 22, 23, 25). Areola openings round or transapically slightly elongated forming uniseriate striae extending onto the mantle, 35-40 in $10 \mu \mathrm{m}$ (Figs 23, 25). Internally, broad virgae separating narrow striae without struts across the vimines, areola openings 

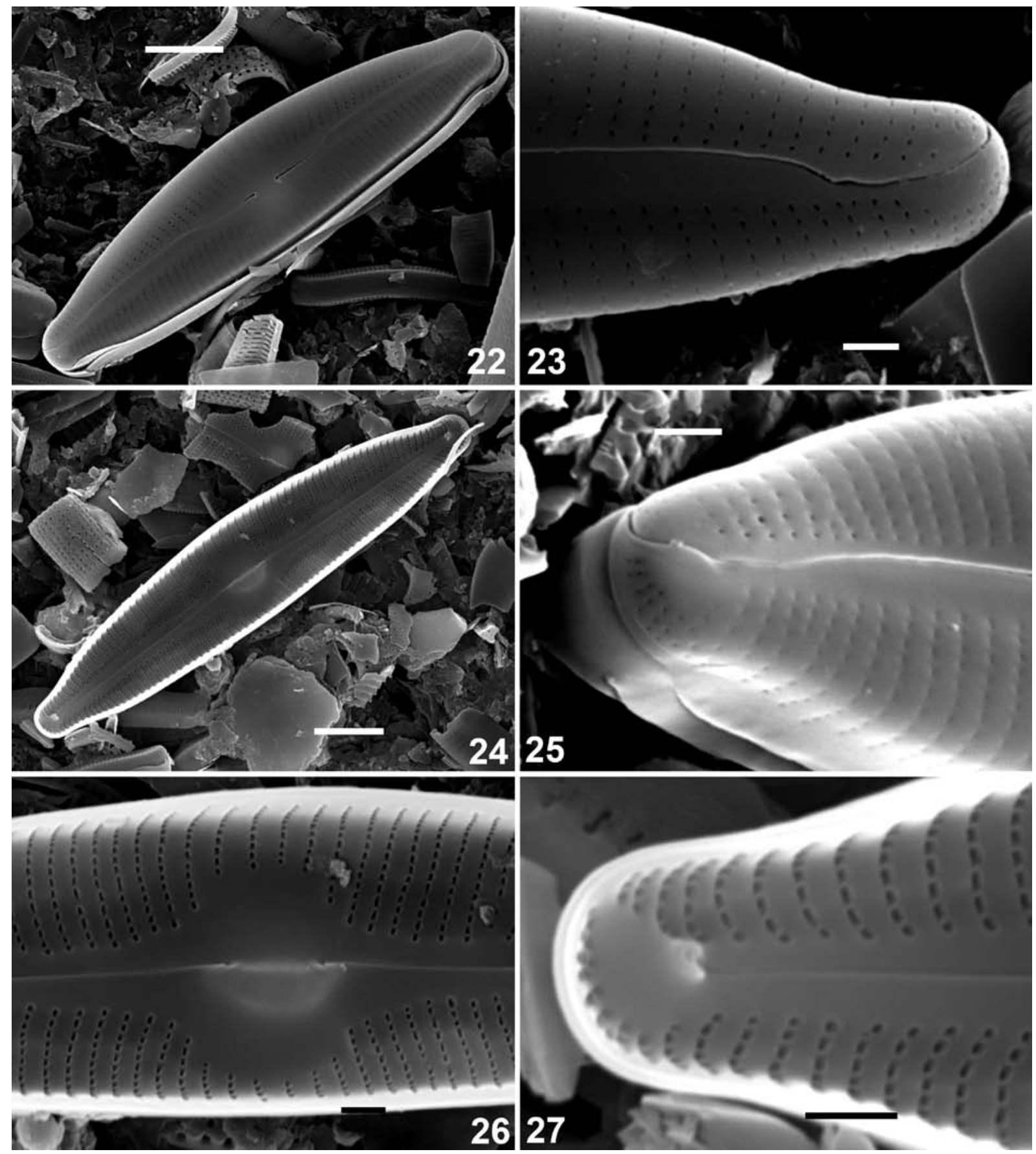

Figs 22-27. Cymbopleura gokyoensis, SEM: stub NMW.C.2009.003 G3-3 main inlet puddle near stream, exposed soil: (22, $23,25)$ external views, (22) whole valve, (23) apex with dorsally deflected raphe ending, (25) valve apex with striae extending around the apex; $(24,26,27)$ internal views, $(24)$ whole valve, $(26)$ valve centre with widely separate central raphe endings against central nodule, (27) valve near apex with helictoglossa, broad virgae and narrow striae without struts over the vimines. Scales bar $5 \mu \mathrm{m}$ (Figs 22, 24); $1 \mu \mathrm{m}$ (Figs 23, 25-27).

lacking occlusions. Raphe slit with internal central endings widely separated on the dorsal side of the asymmetrical central nodule, ending near the apices in small, knob-like helictoglossae adjacent to the first long stria (Figs 24, 26, 27).

Taxonomical remarks. Cymbopleura gokyoensis is similar to Cymbopleura deviatkinii LANGE-
Bert. \& DOROFEYUK found in a Sphagnum bog in the Hentei highlands of Mongolia. The latter has wider valves $(8.7-10 \mu \mathrm{m}$ vs. $6.5-8.5 \mu \mathrm{m})$, subcapitate apices and a smaller central area that merges gradually into the axial area (KULIKOVSKIY et al. 2009). Cymbopleura naviculiformis (Auersw.) Krammer has capitate apices, wider valves $(9-13 \mu \mathrm{m}$ vs. $6.5-8.5 \mu \mathrm{m})$ and a lower 
dorsal stria density (12-14 in $10 \mu \mathrm{m}$ vs. $15-17$ in $10 \mu \mathrm{m})$ in the middle of the valve. Cymbopleura gondwana has wider valves (11-15 $\mu \mathrm{m}$ vs. 6.5$8.5 \mu \mathrm{m})$ with a more convex dorsal margin, and lower dorsal stria density (13-15 in $10 \mu \mathrm{m}$ vs. 15-17 in $10 \mu \mathrm{m}$ ). Cymbopleura linearis (FogED) KRAMMER has more capitate apices. Cymbopleura sublanceolata KRAMMER has longer rostrate apices, wider valves $(10-12 \mu \mathrm{m}$ vs. $6.5-8.5 \mu \mathrm{m})$ and lower stria density (12-14 in $10 \mu \mathrm{m}$ vs. $15-17$ in $10 \mu \mathrm{m}$ ). Cymbopleura fluminea (R.M.PATRICK et Fraser) Lange-Bert. et Krammer has less dorsiventral valves with more broadly rounded apices and lower stria density (10-13 in $10 \mu \mathrm{m}$ vs. $15-17$ in $10 \mu \mathrm{m})$. Cymbopleura frequens var. saxonica KRAMMER has a smaller central area and a lower stria density (11-14 in $10 \mu \mathrm{m}$ vs. $15-17$ in $10 \mu \mathrm{m})$. Cymbopleura subaequalis var. perpunctata (GRUNOW) KRAMmer has less dorsiventral valves, a smaller central area and a lower stria density (10-14 in $10 \mu \mathrm{m}$ vs. $15-17$ in $10 \mu \mathrm{m})$. Cymbopleura hustedtiana KRAMMER has longer, broader apices, a smaller central area and a lower stria density (11-13 in $10 \mu \mathrm{m}$ vs. $15-17$ in $10 \mu \mathrm{m})$. Cymbella tasmaniensis Hust. is larger (58-75 $\mu \mathrm{m}$ and $10-13 \mu \mathrm{m}$ vs. $27-49 \mu \mathrm{m}$ and 6.5$8.5 \mu \mathrm{m})$, and has a wider axial area merging with the similar width central area.

Two other similar diatoms have been found in China, north of the Everest region (Li et al. 2007). One, identified as Cymbopleura linearis, occurred above $4500 \mathrm{~m}$ a.s.l, in a stream in Dingri County and in a swamp in Nielamu Country. The other, identified as $C$. naviculiformis, occurred over a wider altitude range from $2350-5000 \mathrm{~m}$ in springs, streams and swamps, but is very similar to C. gokyoensis.

Ecology. Cymbopleura gokyoensis occurred on exposed, moist soil in a small puddle adjacent to the main inlet of the $3^{\text {rd }}$ lake, but it was not abundant (Table 1). Accompanying taxa included several species in the Achnanthidium minutissimum complex, Cymbopleura cf. venetaeformis, Brachysira brebisonii, Cymbopleura oblongata var. parva, and several as yet unidentified araphid taxa and species of Gomphonema, Eunotia, Pinnularia and Aulacoseira. It was also found on exposed macrophytes and sediment next to an inlet of the $3^{\text {rd }}$ lake on its western side, and occurred rarely on exposed bryophytes, and submerged on sediment, sand, stones and filamentous algae in four springs.
Cymbopleura cf. gondwana LANGE-Bert., Krammer et RUMrich

LM MORPHOLOGY (Figs 28-36). Valves dorsiventral with rostrate apices, strongly convex dorsal margin and convex ventral margin, the latter sometimes almost straight near the valve centre, particularly in smaller valves. Valve dimensions ( $\mathrm{n}=16$ ): Length 21-49 $\mu \mathrm{m}$, width 8-12 $\mu \mathrm{m}$, length/width ratio 2.6-4.1. Narrow, lanceolate axial area widening slightly towards the valve centre. Central area rounded to rhomboidal and slightly asymmetrical, $1 / 3$ to $1 / 2$ of the valve width. Raphe lateral with proximal raphe ends deflected slightly towards the ventral side. Prominent central nodule. Striae radiate throughout the entire valve, $12-14$ in $10 \mu \mathrm{m}$ (dorsal), $14-16$ in $10 \mu \mathrm{m}$ (ventral), up to 20 in $10 \mu \mathrm{m}$ towards the apices. Pores not discernable.

SEM morphology (Figs 37-40). Externally, raphe branches slightly curved ventrally near the valve centre and proximal raphe endings slightly deflected towards the ventral side, distal raphe endings deflected towards the dorsal side (Fig. 37). Internally, raphe slit with central endings deflected onto the dorsal side of the central nodule, ending near the apices in small, knob-like helictoglossae adjacent to the shortened striae (Figs 38, 39). The shortened striae continue around the apex with a gap at the apex. Internally, broad virgae separating narrow striae without struts over the vimines, areola openings lacking occlusions (Fig. 40).

Taxonomical remarks. The identity of the Himalayan specimens is not entirely clear. The valves of the type population of Cymbella (Cymbopleura) gondwana LANGE-BerT., KRAMMER et Rumrich (in Rumrich et al. 2000, figs 119: 6-11, 121: 5, 6) from Patagonia are larger (length $38-60 \mu \mathrm{m}$, width $11-15 \mu \mathrm{m}$ ), although there is some overlap with the Himalayan populations (length $21-49 \mu \mathrm{m}$, width $8-12 \mu \mathrm{m}$ ). The dorsal stria density of the type population is also slightly lower than in the Himalayan populations (11-12 in $10 \mu \mathrm{m}$ vs. $12-14$ in $10 \mu \mathrm{m})$. Other characters, such as the rostrate apices, stria orientation, the slightly ventrally deflected proximal raphe endings, the visible internal central raphe endings (intermissio sensu Krammer), and the shape and size of the central and axial areas are identical. It is possible that the type population did not cover the entire life cycle. Further investigations of populations from both geographical areas are 
required to establish whether they are the same species or whether the Himalayan populations belong to an undescribed taxon.

RUMrich et al. (2000) mentioned that smaller valves resemble Cymbella naviculiformis, however, in the Himalaya, these two taxa can be readily distinguished as $C$. naviculiformis has subcapitate apices and narrower valves. On the other hand, some of the smaller valves of $C$. cf. gondwana in the Himalaya resemble Cymbopleura hercynica (A. SCHMIDT) KRAMMER (KRAMMER 2003, p. 72). Cymbella hercynica is smaller than the type population of $C$. gondwana $(16-40 \mu \mathrm{m}$, $7-10 \mu \mathrm{m}$ vs. $38-60 \mu \mathrm{m}, 11-15 \mu \mathrm{m})$ but its size overlaps with $C$. cf. gondwana from the Himalaya (21-49 $\mu \mathrm{m}, 8-12 \mu \mathrm{m})$. However, in C. hercynica the ventral valve margin appears almost straight near the valve centre, and the proximal raphe endings are more clearly deflected to the ventral side. LI et al. (2007) found C. hercynica in a spring at $2380 \mathrm{~m}$ a.s.l. in the Zhangmu area and another similar species, $C$. hustedtiana KRAMMER, in a swamp at $4750 \mathrm{~m}$ in Nielamu area, both in the Everest region of China, but they did not record C. gondwana.

Ecology. This species was regularly found on exposed sand next to the main inlet of the $3^{\text {rd }}$ lake (Table 1). Accompanying taxa included several species in the Achnanthidium minutissimum complex, Fragilaria vaucheriae (KÜtz.) Petersen and other unidentified Fragilaria species, Psammothidium bioretii (Germain) BUKht. \& Round, Encyonema minutum (HiLse) D.G. ManN, Encyonema cf. brevicapitatum KRAMMER, Diatoma mesodon (EHRENB.) Kütz. and Pseudostaurosira pseudoconstruens (MARCINIAK) D.M.WILLIAMS $\&$ Round. It was rarely found on sediment and bryophytes in two springs.

\section{Cymbopleura naviculiformis}

KRAMMER

(Auersw.)

LM morphology (Figs 41-47). Valves dorsiventral with strongly convex dorsal and convex ventral margins, and subcapitate apices. Valve dimensions $(\mathrm{n}=12)$ : length $26.5-36.4 \mu \mathrm{m}$, width 8.0-9.0 $\mu \mathrm{m}$, length/width ratio 3.1-4.0. Axial area narrow linear or slightly widened towards the central area, rounded to rhomboidal central area, sometimes slightly asymmetrical with a larger dorsal area, ca. $1 / 2$ of the valve width. Raphe lateral, slightly eccentric with ventrally deflected proximal raphe endings. Striae radiate throughout the entire valve, slightly more widely spaced at the valve centre, $12-16$ in $10 \mu \mathrm{m}$ (dorsal), 16-17 in $10 \mu \mathrm{m}$ (ventral), towards the apices 20-23 in 10 $\mu \mathrm{m}$. Pores barely discernible.

SEM morphology (Figs 48-51). Externally, raphe slightly undulate, proximal raphe endings expanded and slightly ventrally deflected, distal raphe endings dorsally deflected (Fig. 48). Areola openings oval and irregularly positioned, c. 3540 in $10 \mu \mathrm{m}$, forming uniseriate striae. Internally, central raphe endings forming small hooks, on the dorsal side of the central nodule. Raphe terminating in small knob-like helictoglossae adjacent to the shortened striae. Shortened striae continuing around the apex with a gap at the apex (Figs 49-51). Broad virgae separating narrow striae with struts over the vimines present, areola openings lacking occlusions (Figs 50, 51).

Taxonomical remarks. There are slight differences between the populations from the Himalaya and those from Europe. The valves from the Himalaya have a slightly more convex ventral margin than most of the specimens shown by KRAMMER (2003, plate 76), and slightly higher areola and stria density towards the apices. Other characters and valve dimensions are identical, and we therefore suggest that the Himalayan specimens are conspecific with those from Europe. A similar species, Cymbopleura pernaviculiformis Kulikovskiy, Lange-Bert. et Dorofeyuk, with slightly wider valves $(10-10.7 \mu \mathrm{m})$ was described from a bog in the Hentei highlands in Mongolia, and is distributed across Central Asia and in the Yugorsky Shar Strait area, on the Arctic Ocean coast (KulikovskiY et al. 2009). Cymbopleura laticapitata (KRAMmer) KULIKOVSKIY et LANGEBERT. from Swedish Lapland has broader apices and is more linear, with a weakly convex dorsal margin. Cymbopleura deviatkinii KULIKOvsKIY, Lange-Bert. et Dorofeyuk (in Kulikovskiy et al. 2009), also described from Mongolia, has a more elongated central area and broader, rostrate apices.

Ecology. This species was common on exposed sand adjacent to the main inlet of the $3^{\text {rd }}$ lake, and on submerged sand in one spring (Table 1). Accompanying taxa included several species in the Achnanthidium minutissimum complex, Fragilaria vaucheriae, other unidentified Fragilaria species and araphid taxa, Psammothidium bioretii, 

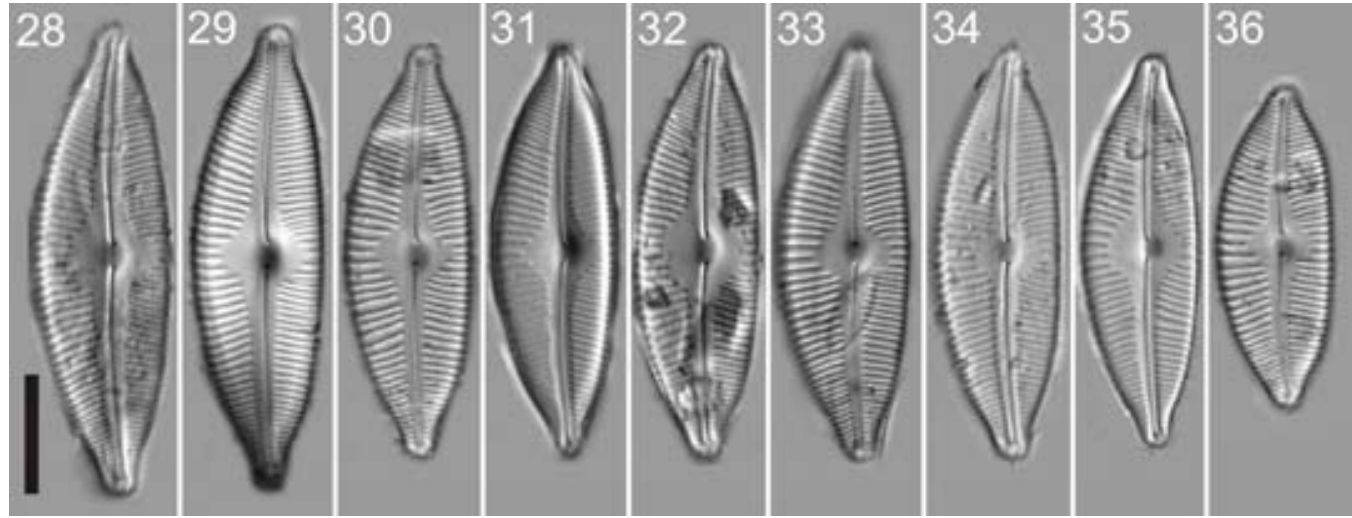

Figs 28-36. Cymbopleura cf. gondwana, LM: (29, 30, 34, 35, 36) slide NMW.C.2009.003 G3 inlet north slope, exposed brown sand; (28, 31-33) NMW.C.2009.003 G3 inlet north slope, exposed sand. Valve views. Scale bar $10 \mu \mathrm{m}$.
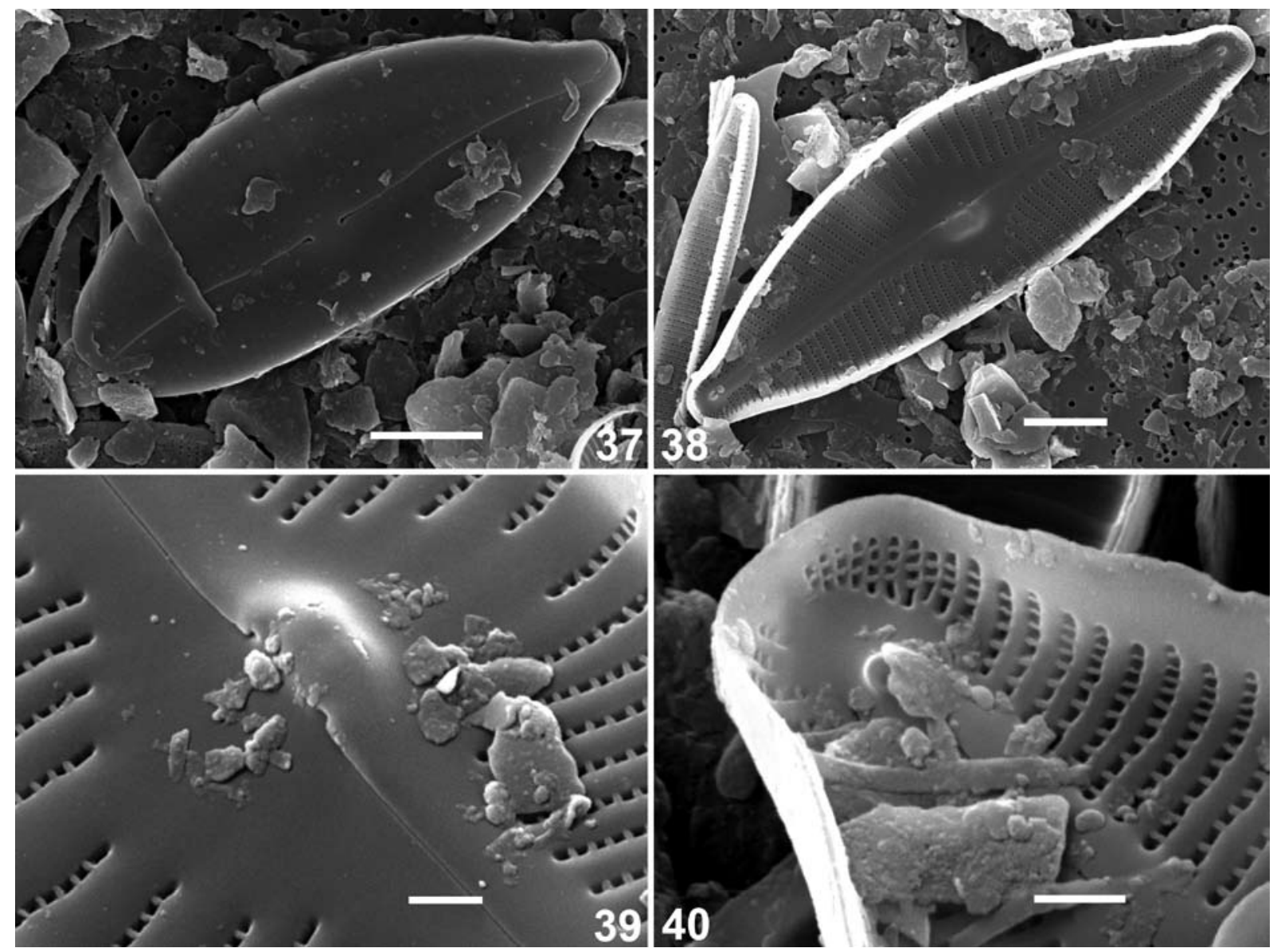

Figs 37-40. Cymbopleura cf. gondwana, SEM: stub NMW.C.2009.003 G3 inlet north slope, exposed sand: (37) external view; (38-40) internal views; $(37,38)$ whole valves; (39) valve centre with central raphe endings deflected onto central nodule; (40) valve near apex with broad virgae and narrow striae without struts over the vimines. Scales bar $5 \mu \mathrm{m}$ (Figs 37, 38); $1 \mu \mathrm{m}$ (Figs $39,40)$.

Psammothidium marginulatum (GRUNOw) BuKHT. et Round, Psammothidium cf. lacus-vulcani (LANGE-Bert. et Krammer) L. BukHT. (Cocconeis thienemannii sensu J.R.CARTER), Encyonema minutum, Encyonema cf. brevicapitatum,
Cymbella himalaspera JÜTTNER et VAN DE VIJVER, Cymbella cf. hantzschiana KRAMMER, Diatoma mesodon, Pseudostaurosira pseudoconstruens, Nitzschia cf. hantzschiana RABENH. and Denticula sp. It was rarely found on exposed macrophytes 

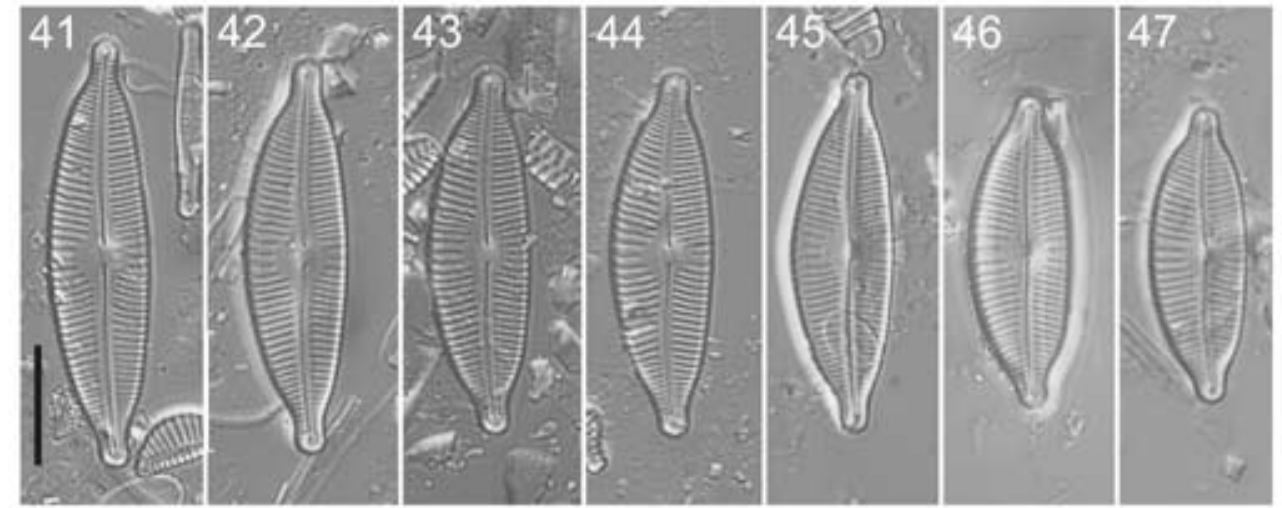

Figs 41-47. Cymbopleura naviculiformis, LM: (41, 42, 44, 45, 47) slide NMW.C.2009.003 G3 inlet north slope, exposed brown sand; $(43,46)$ slide NMW.C.2009.003 G3 inlet north slope, exposed sand. Valve views. Scale bar $10 \mu \mathrm{m}$.
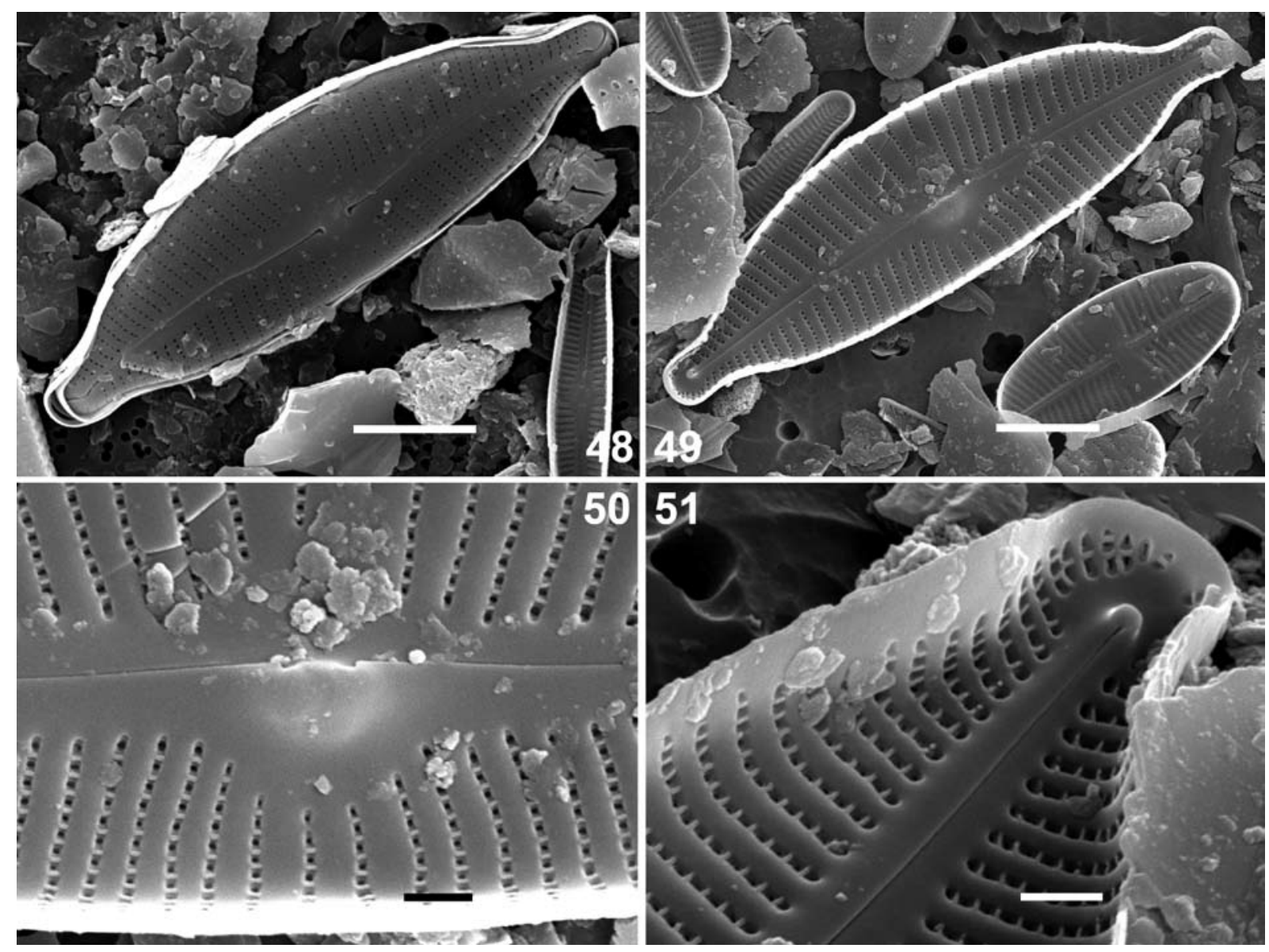

Figs 48-51. Cymbopleura naviculiformis, SEM: (48-51) stub NMW.C.2009.003 G3 inlet north slope, exposed sand; (48) external view; (49-51) internal views; $(48,49)$ whole valves; $(50)$ valve centre with hooked central raphe endings and central nodule, broad virgae and narrow striae with struts over the vimines; (51) valve near apex with helictoglossa and shortened striae. Scales bar $5 \mu \mathrm{m}$ (Figs 48, 49); $1 \mu \mathrm{m}$ (Figs 50, 51).

beside the inlet of the $3^{\text {rd }}$ lake on its western side, and on bryophytes and sediment in three other springs.

\section{Cymbopleura cf. linearis (Foged) KRAMMER} LM morphology (Figs 52-55). Valves dorsi- ventral with a slightly convex dorsal and a very slightly concave ventral margin, and with subcapitate apices. Valve dimensions $(n=5)$ : length $25.2-30.2 \mu \mathrm{m}$, width 5.9-6.4 $\mu \mathrm{m}$, length/ width ratio 4.0-4.9. Axial area narrow, linear. Large, rhomboidal central area bordered by $3-5$ 
very short marginal striae and straight or slightly curved longer striae. Raphe lateral, positioned close to the midline of the valve. Proximal raphe endings ventrally deflected. Striae radiate throughout the valve, 18-20 in $10 \mu \mathrm{m}$ (dorsal), 20 in $10 \mu \mathrm{m}$ (ventral), $22-24$ in $10 \mu \mathrm{m}$ towards the apices. Pores not discernible.

Taxonomical remarks. Except for its size and stria density, the Himalayan specimens conform to Cymbopleura linearis (Foged) Krammer. The specimens depicted by KRAMMER (2003), apart from one photo of the type from Alaska, are all from Swedish and Finnish Lapland. They are slightly larger (length 33-44 $\mu \mathrm{m}$, width $7.8-8.7$ $\mu \mathrm{m})$ and have a lower stria density (14-15 in $10 \mu \mathrm{m}, 18$ towards the apices) than those in the Himalaya.

Ecology. This species was very rare and only observed on moist sand beside the main inlet of the $3^{\text {rd }}$ lake (Table 1).

\section{Cymbopleura anglica (LAGERST.) Krammer} LM morphology (Figs 56-60). Valves broadly elliptic and only slightly dorsiventral with a strongly convex dorsal and a convex ventral margin, and pronounced, rostrate apices. Valve dimensions: length 34.7-41.4 $\mu \mathrm{m}$, width 13.4 $14.9 \mu \mathrm{m}$, length/width ratio 2.6-2.9. Axial area narrow, linear, widening slightly towards the rounded central area, which occupies ca. 1/3 (rarely $1 / 2$ ) of the valve width and is sometimes slightly asymmetrical. Raphe lateral, near the
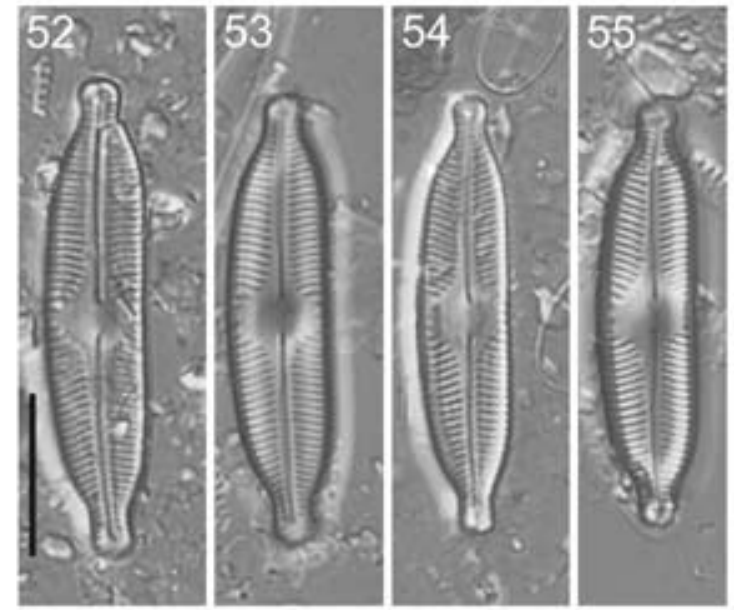

Figs 52-55. Cymbopleura cf. linearis, LM: $(52,53)$ slide NMW.C.2009.003 G3 inlet north slope, exposed sand; (54, 55) slide NMW.C.2009.003 G3 inlet north slope, exposed brown sand. Valve views. Scale bar $10 \mu \mathrm{m}$. midline of the valve. Striae radiate throughout the valve, straight or slightly curved (variable within one valve), density 9-10 in $10 \mu \mathrm{m}$ (dorsal), 11-12 in $10 \mu \mathrm{m}$ (ventral), $15-18$ in $10 \mu \mathrm{m}$ towards the apices. Pores discernable.

SEM morphology (Figs 61-62). due to the rarity of the species, only one eroded specimen was observed in SEM. Externally, central raphe endings enlarged and deflected towards the ventral side forming a small hook. Striae uniseriate, composed of apically elongated, I-shaped areolae, c. 25 in $10 \mu \mathrm{m}$.

Taxonomical remarks. The specimens from the Himalaya conform to the description of C. anglica. The valve width in the Himalayan population is at the lower end of the range (13.4-14.9 $\mu \mathrm{m}$ vs. 14.7-17.6 $\mu \mathrm{m}$ ) given by Krammer (2003).

Ecology. This species was rare and found on sand in the littoral of the $3^{\text {rd }}$ lake, on exposed sand adjacent to the inlet of the $3^{\text {rd }}$ lake, and on exposed macrophytes beside the inlet of the $3^{\text {rd }}$ lake on its western side (Table 1).

\section{Cymbopleura ef. mongolica Metzeltin, LANGe- Bert. et Nergui}

LM morphology (Figs 63-65). Valves ellipticlanceolate and almost symmetrical with convex dorsal and ventral margins and subcapitate apices. Valve dimensions $(\mathrm{n}=12)$ : length $39.3-42.6 \mu \mathrm{m}$, width 9.9-11.1 $\mu \mathrm{m}$, length/width ratio 3.7-4.3. Axial area 2.2-2.4 $\mu \mathrm{m}$ wide, with undulating margins. Central area rectangular, occupying more than half the valve width, occasionally smaller and rounded, usually bordered by five shortened striae and curved longer striae. Raphe slightly lateral along the midline of the valve. Striae radiate, straight to slightly curved, becoming more strongly radiate towards the apices, 17-19 in $10 \mu \mathrm{m}$. Pores discernible.

SEM morphology (Figs 66-71). Externally, raphe branches straight with enlarged proximal raphe endings, which are usually ventrally bent, but sometimes almost straight (Figs 66-68). Distal raphe endings dorsally deflected (Figs 66, 69). Striae uniseriate, composed of transapically elongated, slit-like areolae extending onto the mantle, areolae sometimes becoming more rounded towards the valve margin, $30-35$ in 10 $\mu \mathrm{m}$. Shortened striae with slightly elongated, rounded areolae present around the apices, 

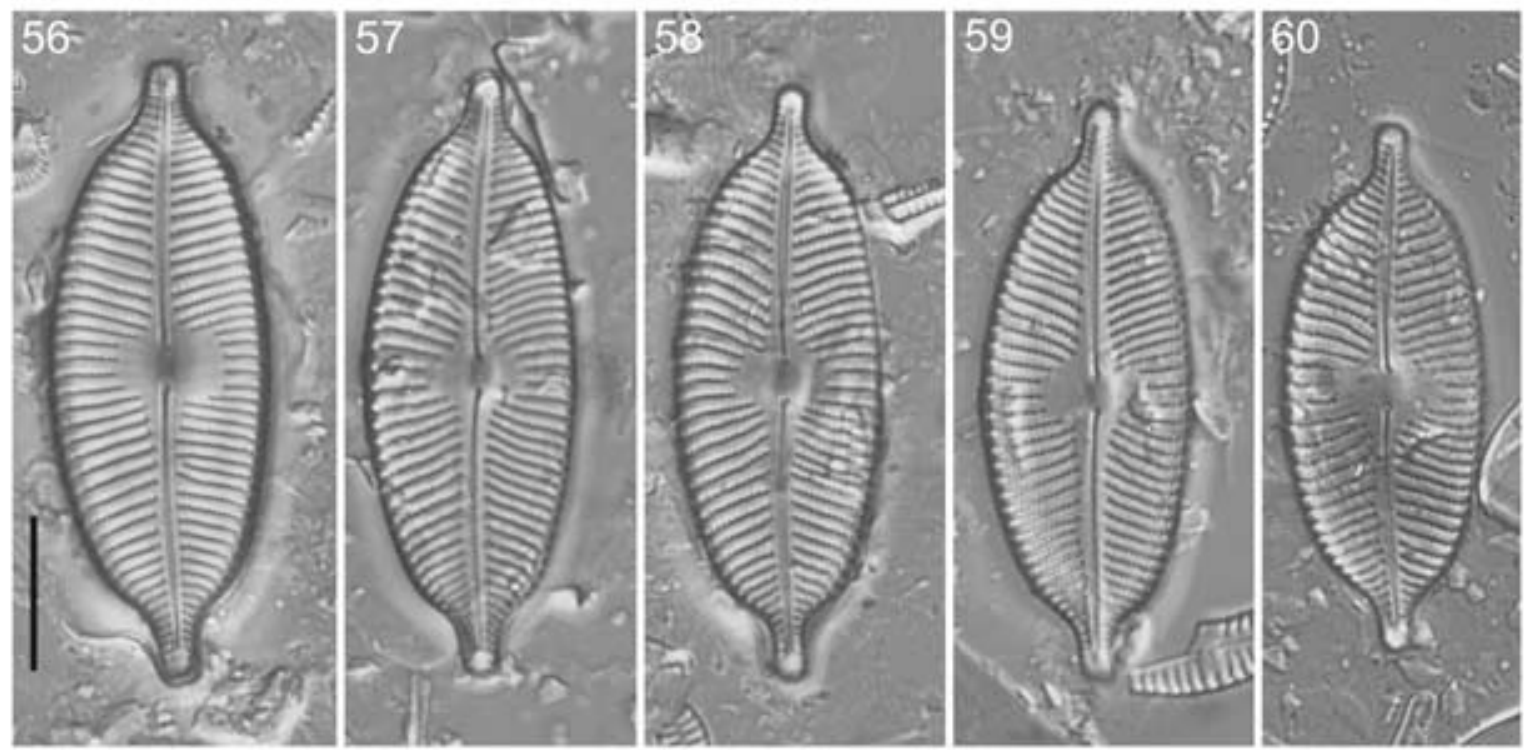

Figs 56-60. Cymbopleura anglica, LM: (56, 58, 59) slide NMW.C.2009.003 18, G3 lake littoral near main inlet, sand; (57) slide NMW.C.2009.003 10, G3 lake littoral near outlet, exposed sediment; (60) slide NMW.C.2009.003 G3 inlet north slope, exposed sand. Valve views. Scale bar $10 \mu \mathrm{m}$.
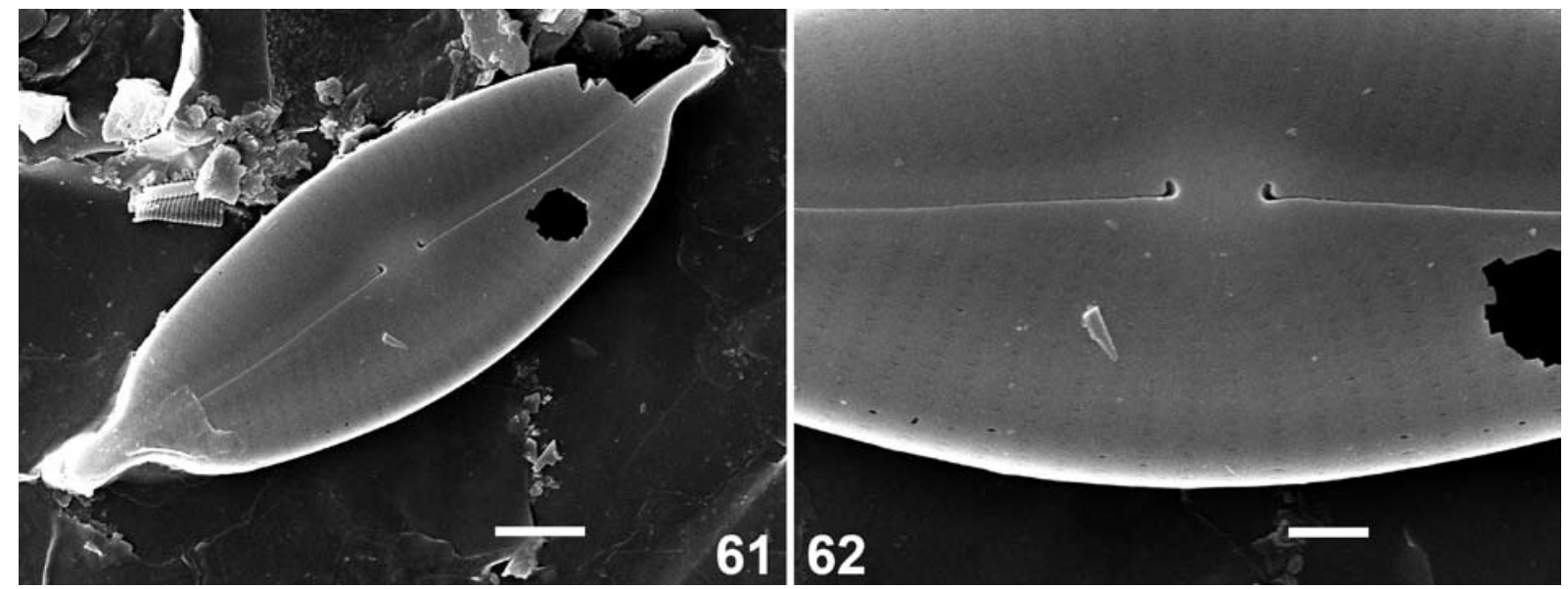

Figs 61-62. Cymbopleura anglica, SEM: stub NMW.C.2009.003 18, G3 lake littoral near main inlet, sand. External views: (61) whole valve; (62) valve centre with ventrally deflected raphe endings. Scale bar $5 \mu \mathrm{m}$ (Fig. 61); $2 \mu \mathrm{m}$ (Fig. 62).

bisected by the distal raphe endings (Figs 69, 70). Internally, central raphe endings slightly deflected, polar endings terminating in small knob-like helictoglossae adjacent to the first longer stria. Broad virgae separating narrow striae (Fig. 71).

Taxonomical remarks. The identity of the Himalayan population is not entirely clear. It only differs from the type of Cymbopleura mongolica Metzeltin, Lange-Bert. et Nergui, found on plants in Lake Khokh, Mongolia, by its smaller dimensions (39.3-42.6 $\mu \mathrm{m}, 10-10.8 \mu \mathrm{m}$ vs. $50-58$ $\mu \mathrm{m}, 12.5-14 \mu \mathrm{m})$ and slightly higher stria density (17-19 in $10 \mu \mathrm{m}$ vs. $15-17$ in $10 \mu \mathrm{m})$. Li et al. (2007) found a species similar to the Gokyo taxon, in a spring and stream at ca. $5000 \mathrm{~m}$ a.s.1. in Dingri County, China, north of the Everest region, and referred to it as Cymbopleura elliptica KRAMmer. However, C. elliptica from northern Germany, Sweden, Finland and Alaska (KRAmmer 2003) has a lower stria density (10-13 in $10 \mu \mathrm{m}$ vs. $17-19$ in $10 \mu \mathrm{m})$, a rhomboidal central area, and the striae are mostly straight, not slightly curved as in $C$. cf. mongolica. Cymbopleura lura Miнo et KRAMMER from Albania has a smaller roundish central area, lower stria density (10-11 in $10 \mu \mathrm{m})$ and higher areola density (40-44 in $10 \mu \mathrm{m}$, KRAMMER 2003). A similar taxon, though with more pronounced shoulders, was found in France in the Massif de l'Oisansandidentified as Cymbellastauroneiformis 


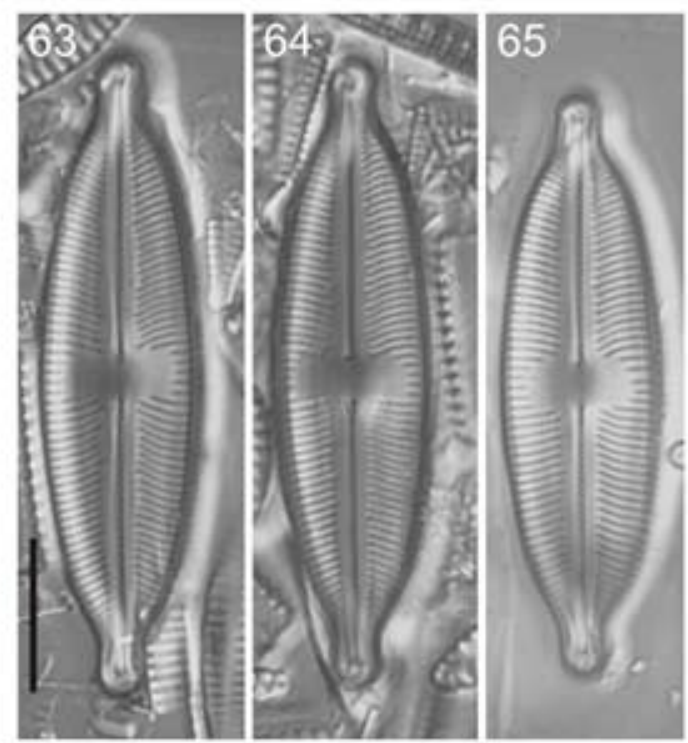

Figs 63-65. Cymbopleura cf. mongolica, LM: slide NMW.C.2009.003 G3 spring 4 bryophytes. Valve views. Scale bar $10 \mu \mathrm{m}$.

by Le COHU (1996). The ultrastructure of the French specimens is similar to that of the specimens from Nepal including the internal central raphe endings and the structure of the areolae. Compared with the iconotype in LAGERSTEDT (1873), the French taxon does not belong to Cymbopleura (Cymbella) stauroneiformis, but more probably belongs to $C$. (cf.) mongolica.

Ecology. Cymbopleura mongolica was one of the most frequently recorded Cymbopleura species in the Gokyo area, although it often occurred at low abundances (Table 1). The largest population was found on bryophytes in one spring (spring 4, 2008) where it was accompanied by several unidentified araphid taxa, F. vaucheriae, Denticula sp., D. mesodon, E. cf. brevicapitatum, C. himalaspera and Eunotia sp. It also regularly occurred on moist soil adjacent to the main inlet of the $3^{\text {rd }}$ lake and was rarely found on sediment, sand, filamentous algae, bryophytes and rock in three other springs and on moist soil in a puddle beside the main inlet of the $3^{\text {rd }}$ lake.

\section{Cymbopleura cf venetaeformis P.B.HAMILTON et} D.ANTONIADES

LM morphology (Figs 72-79). Valves almost symmetrical with slightly convex dorsal and ventral margins and rostrate apices. Valve dimensions $(\mathrm{n}=25)$ : length 18.0-34.0 $\mu \mathrm{m}$, width 4.5-5.4 $\mu \mathrm{m}$, length/width ratio 3.9-6.5. Axial area very narrow, linear with filiform raphe along the midline of the valve. Central raphe endings small and straight. Distal raphe endings dorsally deflected. Central area usually more than half the valve width, forming a slightly butterflyshaped, rectangular or rounded area. Two to four shortened striae bordering the central area, other striae slightly curved or straight. Striae radiate sometimes almost parallel at the apices, $18-22$ in $10 \mu \mathrm{m}$. Pores not discernible.

SEM morphology (Figs 80-83). Externally, raphe slightly undulating with very slightly enlarged proximal raphe endings, very slightly deflected to the ventral side (Figs 80, 81). Distal raphe endings dorsally deflected (Fig. 80). Striae uniseriate, composed of transapically slightly elongated areolae, c. 40-50 in10 $\mu \mathrm{m}$ (Fig. 81). Internally, central raphe endings deflected to the same side and terminating on a slightly raised central nodule (Fig. 82). Distal raphe endings terminating in knob-like helictoglossae near the last long transapical stria (Fig. 83). Broad virgae separate narrow striae. Internal areola openings covered by round or slightly oval occlusions, papillae sensu Krammer (1982a, 2003, Figs 82, 83). Shortened striae continue around the apex with a gap at the apex (Fig. 83).

Taxonomical remarks. The species from the Himalaya is similar to Cymbopleura venetaeformis P.B. Hamilton et D. Antoniades, described from Ellesmere Island in the Canadian Arctic (ANTONIADES et al. 2009). The latter was separated from Cymbopleura geofriedana REICHARDT from the Austrian Alps, based on narrower valves, a lower stria density and a more rectangular central area (REICHARDt 2004, ANTONIADES et al. 2009). However, the stria density of $C$. venetaeformis in the published pictures appears to be higher than that given in the description, and similar to that of the Himalayan specimens (ANTONIADES et al. 2008, 2009). The shape of the central area is more rectangular and the striae are less curved in the Canadian and Himalayan specimens compared to C. geofriedana. Cymbella geofriedana also seems to lack occlusions of the internal areola openings and the internal central raphe endings are hidden (REICHARDT 2004). The internal structure of $C$. venetaeformis has not been studied due to the rarity of the species in the sample (P. HAMILTON, pers. comm.) but it would be interesting to know whether this species has internal areola occlusions and visible internal central raphe endings, in 

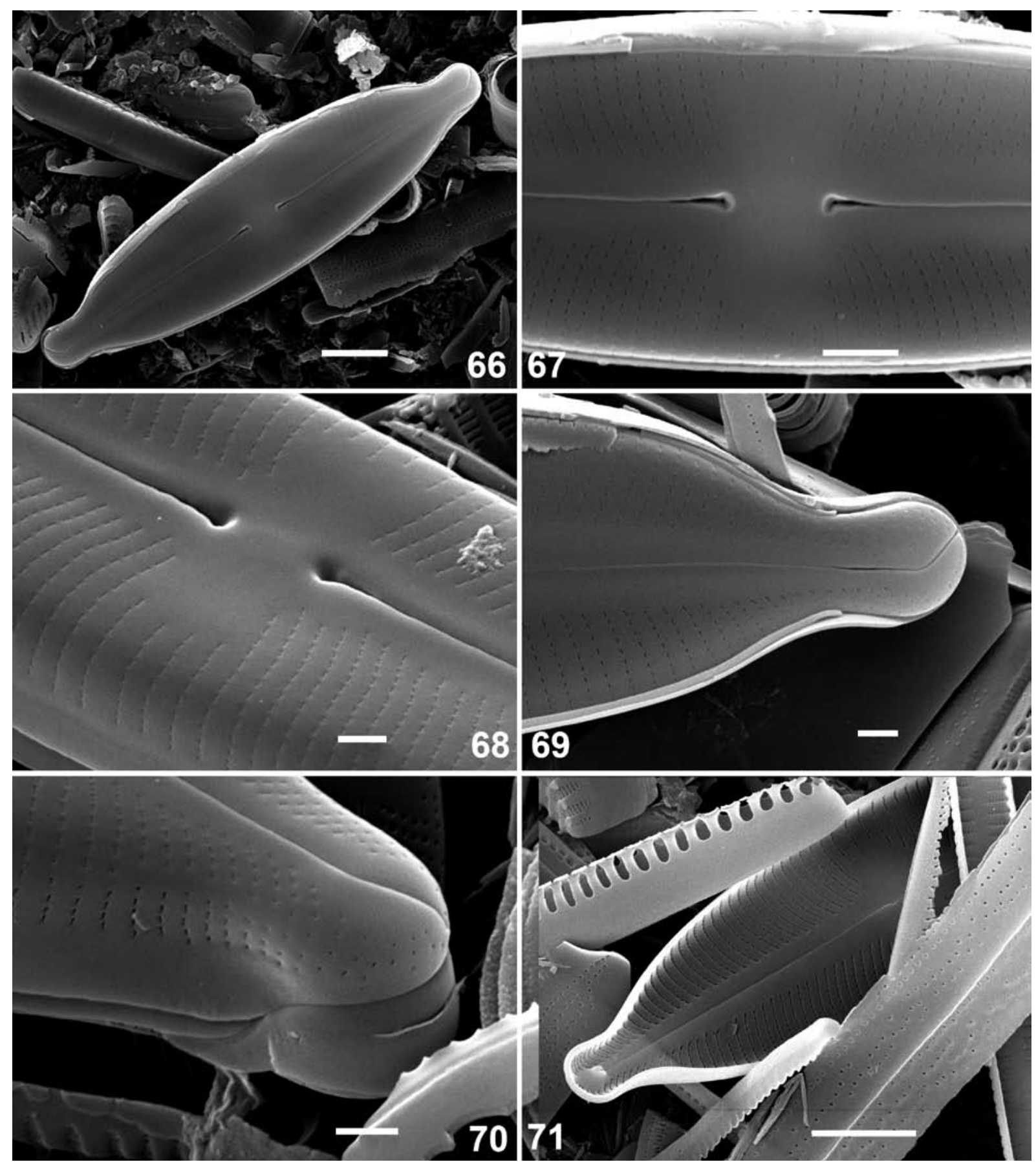

Figs 66-71. Cymbopleura cf. mongolica, SEM: $(66,67)$ stub NMW.C.2009.003 G3-3 main inlet puddle near stream, exposed soil; (68-71) stub NMW.C.2009.003 G3 spring 4 bryophytes; (66-70) external views, (66) whole valve, ( 67) valve centre with slightly ventrally deflected raphe endings, (68) valve centre with central area and striae extending onto mantle, (69) apex with dorsally deflected raphe ending, (70) valve apex with striae extending around the apex; (71) internal view, valve with helictoglossa, broad virgae and narrow striae. Scales bar $5 \mu \mathrm{m}$ (Figs 66, 71); $2 \mu \mathrm{m}$ (Fig. 67); $1 \mu \mathrm{m}$ (Figs 68-70).

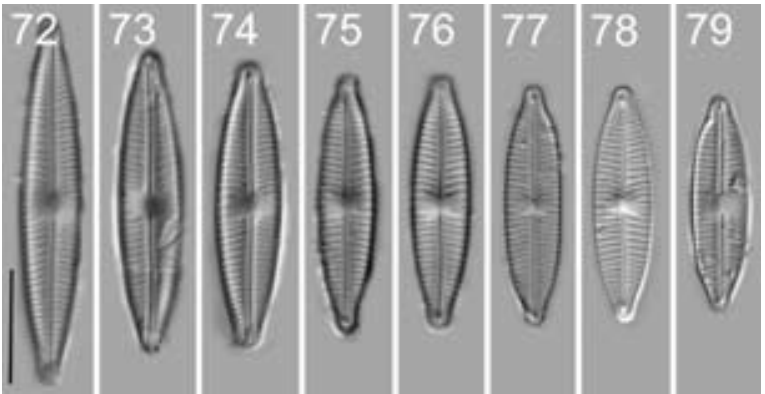

Figs 72-79. Cymbopleura cf. venetaeformis, LM: $(72,73$, 76, 77, 79) slide NMW.C.2009.003 G3-3 main inlet, exposed moist soil; (74, 75, 78) slide NMW.C.2009.003 G3-3 main inlet puddle near stream, exposed soil. Valve views. Scale bar $10 \mu \mathrm{m}$. 

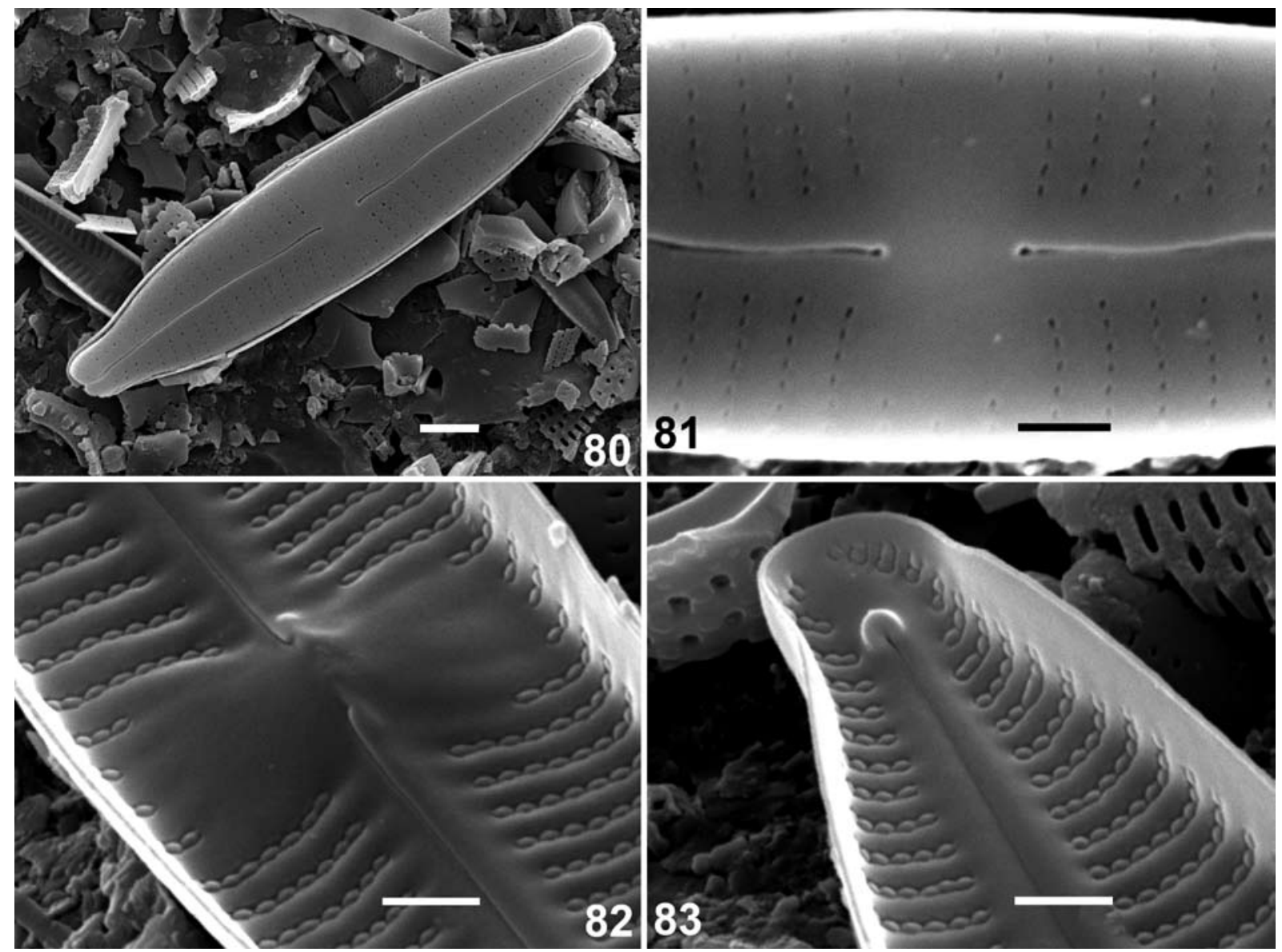

Figs 80-83. Cymbopleura cf. venetaeformis, SEM: stub NMW.C.2009.003 G3-3 main inlet puddle near stream, exposed soil. $(80,81)$ external views, $(80)$ whole valve, $(81)$ valve centre with central area; $(82,83)$ internal views, $(82)$ valve centre with wide space between central raphe endings, broad virgae, striae and areola occlusions, (83) valve near apex with helictoglossa and shortened striae. Scale bar $2 \mu \mathrm{m}$ (Fig. 80); $1 \mu \mathrm{m}$ (Figs 81, 82, 83).

which case we would suggest that the Canadian and Himalayan specimens are conspecific. Cymbopleura stauroneiformis (LAGERST.) KRAMMER is a larger species with more convex valve margins, a rounded central area and a lateral raphe.

Ecology. This species was very abundant on exposed moist soil adjacent to the main inlet of the $3^{\text {rd }}$ lake (Table 1), accompanied by several species in the Achnanthidium minutissimum complex, Cymbopleura cf. venetaeformis, Brachysira brebisonii, Cymbopleura oblongata var. parva, E. cf. brevicapitatum, Encyonema lunatum (W. SM.) VAN HEURCK and several yet unidentified araphid taxa and species of Gomphonema, Eunotia, Pinnularia and Aulacoseira. It was rare on exposed sand beside this inlet, on exposed sediment and on exposed macrophytes by the inlet on the western shore of the lake.
Cymbopleura nadejdae Metzeltin, LangeBert. et Nergui

LM morphology (Figs 84-86). Valves slightly asymmetrical with convex dorsal and ventral margins and rostrate apices. Valve dimensions $(\mathrm{n}=5)$ : length $42.5-60.6 \mu \mathrm{m}$, width 9.5-12.8 $\mu \mathrm{m}$, length/width ratio 4.5-4.8. Axial area lanceolate, central area rhomboidal and asymmetrical, with the larger part on the dorsal side, more than $1 / 2$ of the valve width. Raphe lateral, near the midline of the valve. Proximal raphe endings slightly expanded and ventrally deflected. Striae radiate throughout the entire valve, becoming almost parallel at the apices, 13-14 in $10 \mu \mathrm{m}$ (dorsal), 13-17 in $10 \mu \mathrm{m}$ (ventral). Striae more widely spaced at the valve centre. Pores discernible.

Taxonomical remarks. Only a few valves were found, and although these valves had a slightly lower dorsal stria density than the type of Cymbopleura nadejdae, a species recently 


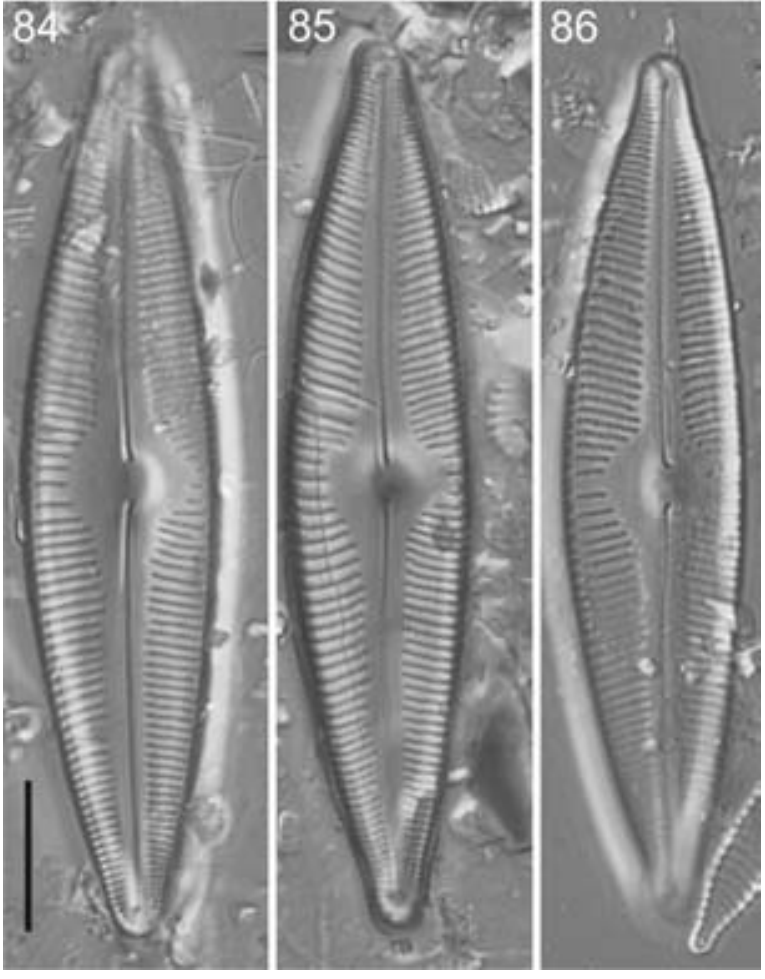

Figs 84-86. Cymbopleura nadejae, LM: slide NMW.C.2009.003 G3 inlet north slope, exposed sand. Valve views. Scale bar $10 \mu \mathrm{m}$.

described from the Khentii Province in Mongolia (12-14 vs. $15-17$ in $10 \mu \mathrm{m}$, Metzeltin et al. 2009), other characters are identical and the species from both regions are probably conspecific. Similar species include Cymbopleura lapponica (GRUNOw) KRAMMER from Lapland, northern Norway, Iceland, Spitsbergen and the European Alps with a smaller rounded central area and a narrower axial area, and C. stauroneiformis (LAGERST.) KRAMmer recorded from Spitsbergen, Bear Island, Iceland and Greenland with narrower apices.

Ecology. This taxon was only observed in very low numbers on exposed sand adjacent to the inlet of the $3^{\text {rd }}$ lake (Table 1 ).

\section{Cymbopleura oblongata var. parva KRAMMER} LM morphology (Figs 87-94). Valves very slightly dorsiventral to symmetrical with very slightly convex to almost straight dorsal and ventral valve margins and very slightly rostrate, broadly rounded apices. Valve dimensions (n = 15): length 28.5-34.7 $\mu \mathrm{m}$, width 5.4-6.3 $\mu \mathrm{m}$, length/width ratio 4.5-5.6. Axial area narrow, lanceolate. Small rounded central area formed by one or two slightly shortened striae, sometimes difficult to distinguish from the axial area. One or two striae at the valve centre more widely spaced. Raphe lateral and slightly eccentric, becoming filiform, near the midline at the valve centre and the apices. Central raphe endings slightly expanded and deflected, sometimes almost straight. Striae radiate becoming almost parallel at the apices, straight or slightly curved. 11-14 in $10 \mu \mathrm{m}$ (dorsal), $12-14$ in $10 \mu \mathrm{m}$ (ventral), becoming $15-18$ in $10 \mu \mathrm{m}$ towards the apices. Pores discernible with difficulty.

SEM morphology (Figs 95-100). Externally, raphe undulating (Fig. 95). Proximal raphe endings slightly enlarged, drop-like, straight or very slightly dorsally or ventrally deflected (Fig. 96). Distal raphe endings dorsally deflected (Fig. 97). Striae uniseriate, composed of round or slightly transapically elongate areolae, extending onto the mantle, ca. 40 in $10 \mu \mathrm{m}$. Shortened striae extending around the apices bisected by the distal raphe endings (Fig. 98). Internally, central raphe endings deflected to the ventral side and abutting the asymmetrical central nodule (Fig. 99). Distal raphe endings terminating in small, knob-like helictoglossae near the areolae of the last long transapical striae. Shortened striae continuing around the apex with a gap at the apex (Fig. 100). Broad virgae separating narrow striae, areolae delimited by obliquely orientated vimines (Figs 99, 100).

Taxonomical remarks. The Himalayan population closely resembles Cymbopleura oblongata var. parva from Spitsbergen (KRAMMER 2003), although the valves are slightly narrower than those from Spitsbergen and Mongolia (5.4 $-6.3 \mu \mathrm{m}$ vs. $6.5-7.4 \mu \mathrm{m})$ and the stria density tends to be slightly higher (11-14 in $10 \mu \mathrm{m}$ vs. $9-12$ in $10 \mu \mathrm{m}$ dorsally near the valve centre, $15-18$ in $10 \mu \mathrm{m}$ vs. up to 15 in $10 \mu \mathrm{m}$ near the apices, Krammer 2003, Metzeltin et al. 2009). Cymbopleura subaequalis (GRUNOw) KRAMMER is similar but can be distinguished by its broad, protracted apices (KRAMMER 2003).

Ecology. This taxon is one of the most widespread Cymbopleura species in the Gokyo area, although at many sites it was only found in small numbers (Table 1). It was abundant found on exposed moist soil in a puddle beside the main inlet of the $3^{\text {rd }}$ lake, accompanied by several species in the Achnanthidium minutissimum complex, Cymbopleura cf. venetaeformis, Brachysira 

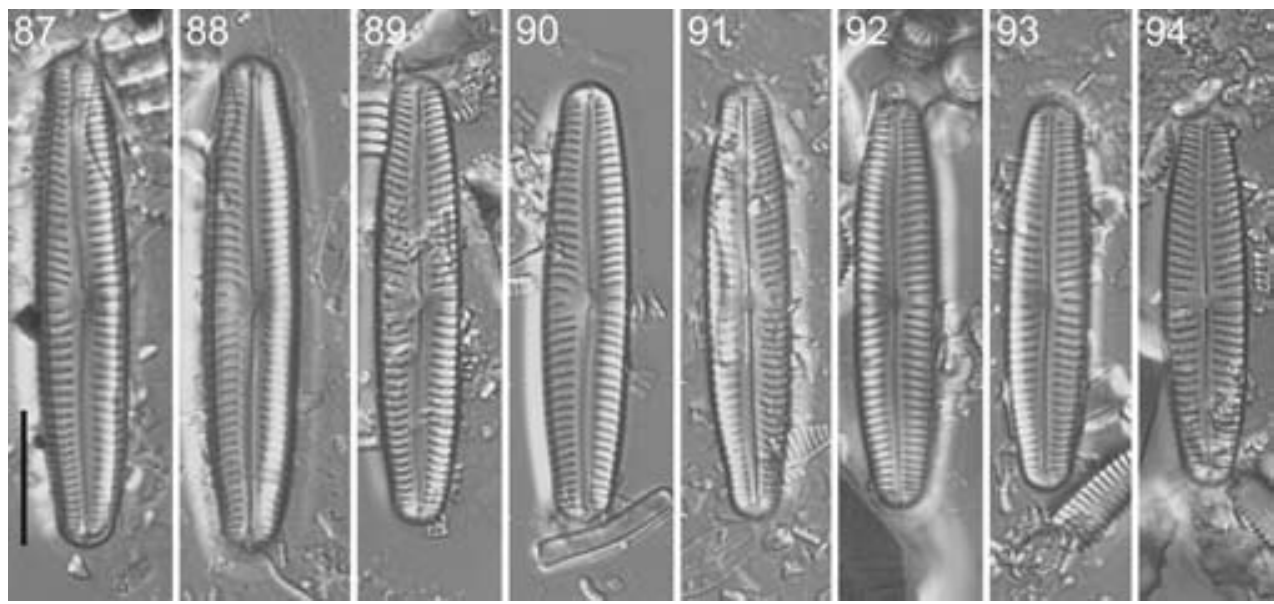

Figs 87-94. Cymbopleura oblongata var. parva, LM: (87, 88, 91) slide NMW.C.2009.003 G3 inlet north slope, exposed sand; (89, 90, 92-94) NMW.C.2009.003 G3-3 main inlet puddle near stream, exposed soil. Valve views. Scale bar $10 \mu \mathrm{m}$.

brebissonii, and several yet unidentified araphid taxa and species of Gomphonema, Eunotia, Pinnularia and Aulacoseira. It was rare on exposed sand adjacent to the main inlet of the $3^{\text {rd }}$ lake, on exposed macrophytes beside the inlet on the western shore of the lake, and on rocks, sediment, bryophytes and filamentous algae in five springs.

\section{Cymbopleura emoda JütTNER et VAN DE VIJVER sp. nov.}

Diagnosis: Valvaeleviter dorsiventrales adsymmetricae marginibus dorsalibus ventralibusque leviter convexis, leviter gibbosis in media parte valvae, apicibus late rotundatis, leviter rostratis. Longitudo 35-40 $\mu \mathrm{m}$, latitudo 6.8-7.7 $\mu \mathrm{m}$, ratio longitudinis/latitudinis 4.95.7. Area axialis angusta, lanceolata. Area centralis rotunda, expansa formans subfasciam marginatam 2-3 striis abbreviatis. Striae centrales distantiores. Raphe lateralis, leviter eccentrica praeter in centro valvae et ad apices. Striae transapicales radiatae, aliquando leviter curvataen parallelae ad apices, 13-16 in 10 $\mu \mathrm{m}, 17-20$ in $10 \mu \mathrm{m}$ ad polos. Puncta discernenda, 30-35 in $10 \mu \mathrm{m}$.

Holotypus: NMW.C.2009.003.G3 inlet north slope, exposed sand

Isotypes: BR-4211, National Botanic Garden of Belgium, Meise, Belgium; Kathmandu University, Aquatic Ecology Centre, Dhulikhel, Nepal; BRM ZU7/95, Hustedt Collection, Alfred-WegenerInstitut für Polar- und Meeresforschung, Bremerhaven, Germany; BM 101482, The Natural History Museum, London, U.K.

Locus typicus: The bank of the main inlet to the $3^{\text {rd }}$ lake (Gokyo Lake) at its northern margin.

Etymology: The specific epithet emoda refers to the ancient Greek name for the Himalaya mountains: Mons emodus.

LM morphology (Figs 101-107). Valves very slightly dorsiventral to symmetrical, with very slightly convex dorsal and ventral valve margins, slightly gibbous at the centre of the valve, with very slightly rostrate, broadly rounded apices. Valve dimensions $(\mathrm{n}=10)$ : length $35-40 \mu \mathrm{m}$, width 6.8-7.7 $\mu \mathrm{m}$, length/width ratio 4.9-5.7. Axial area narrowly lanceolate, merging into a round central area, up to half the valve width, formed by $2-3$ shortened striae on each side. Two central striae often more distantly spaced. Raphe lateral and slightly eccentric, except near the valve centre and the apices where it is filiform and axial. Striae radiate, some slightly curved, becoming almost parallel at the apices, $13-16 / 10 \mu \mathrm{m}, 17-20 \mu \mathrm{m}$ towards the apices. Pores discernible.

SEM morphology (Figs 108-111). Externally, raphe undulating (Fig. 108). Proximal raphe endings slightly enlarged, straight or only very slightly deflected (Fig. 109). Distal raphe fissures dorsally deflected (Fig. 110). Striae uniseriate, extending onto the mantle, composed of $\mathrm{x}$-or irregularly shaped areolae near the valve face/ mantle margins, more $\mathrm{i}$-shaped striae towards the apices, and shortened striae with round areolae, $30-35$ in $10 \mu \mathrm{m}$, extending around the apices. Shortened striae at the apices bisected by the distal raphe endings (Figs 109, 110). Internally, central raphe endings deflected to the ventral side and ending on the side of an asymmetrical central nodule. Distal raphe endings terminating in helictoglossae near the apices. Broad virgae 


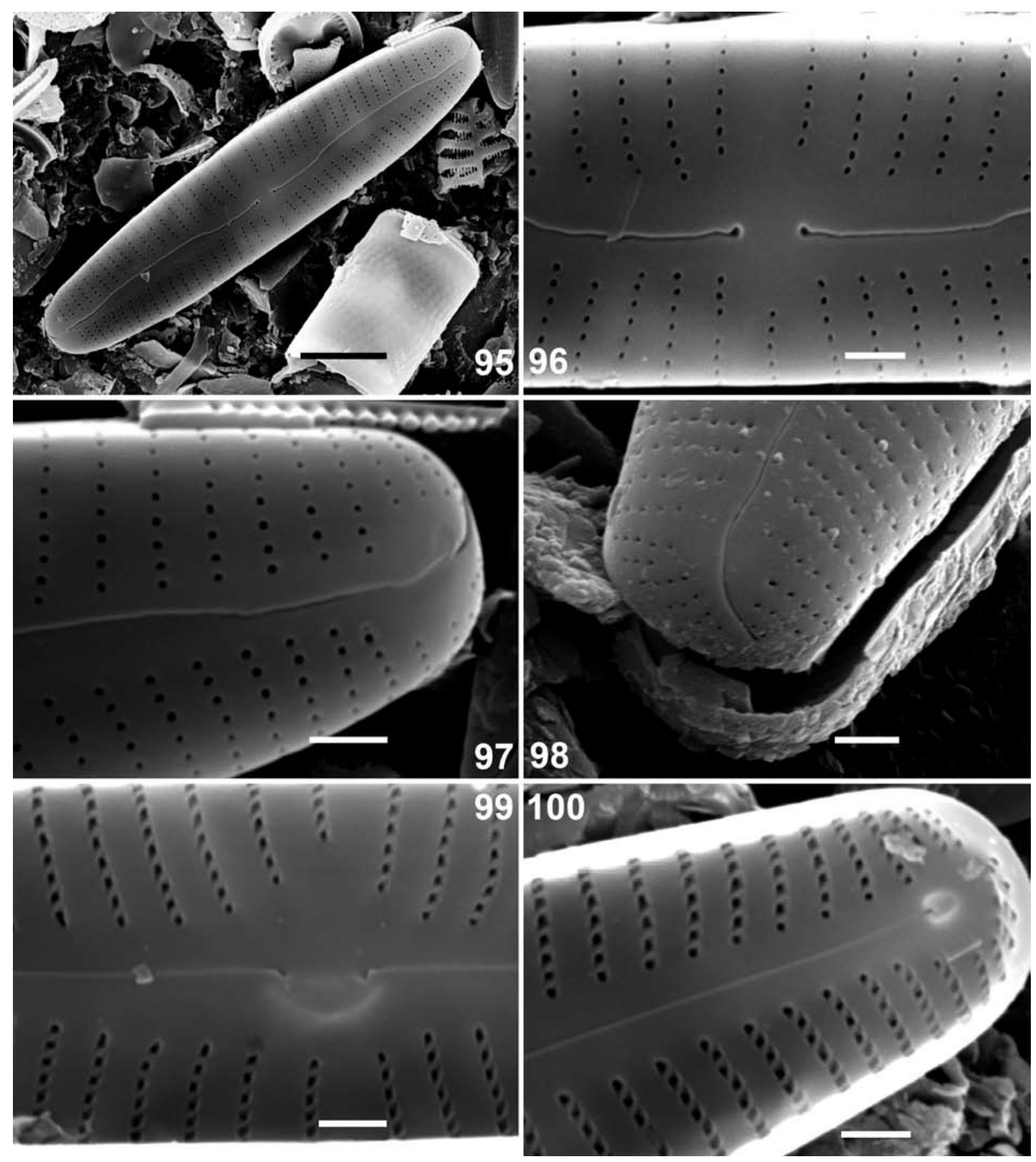

Figs 95-100. Cymbopleura oblongata var. parva, SEM: (95-97, 99) stub NMW.C.2009.003 G3-3 main inlet puddle near stream, exposed soil; $(98,100)$ stub NMW.C.2009.003 G3 inlet north slope, exposed sand. (95-98) external views, (95) whole valve, (96) valve centre with slightly ventrally deflected raphe endings, (97) valve near apex with dorsally deflected raphe endings, (98) valve apex with striae extending around the apex; $(99,100)$ internal views, $(99)$ valve centre with wide gap between central raphe endings, central nodule, broad virgae and narrow striae without struts over the vimines, (100) valve near apex with helictoglossa. Scale bar $5 \mu \mathrm{m}$ (Fig. 95); $1 \mu \mathrm{m}$ (Figs 96-100).

separating narrow striae, areolae delimited by obliquely orientated vimines (Fig. 111).

Taxonomical remarks. Cymbopleura emoda clearly belongs to the complex of species around Cymbopleura subaequalis (GRUNOW) KRAMMER and Cymbopleura oblongata KRAMMER. It differs from Cymbopleura subaequalis v. alpestris KRAMMER by the shape of the areolae, which are $\mathrm{x}-$, irregularly and i-shaped in the Himalayan species, and round to slightly elongate in C. subaequalis v. alpestris (Reichardt 1994, KRAmmer 2003), and by its slightly higher stria density $(13-16 / 10 \mu \mathrm{m}$, $17-20 \mu \mathrm{m}$ towards the apices vs. $10-14$ in $10 \mu \mathrm{m}$ ). 
The valve interior is similar in both taxa.

Cymbopleura emoda is also slightly larger than Cymbopleura oblongata var. parva (35-40 $\mu \mathrm{m}, 6.8-7.7 \mu \mathrm{m}$ vs. $28.5-34.7 \mu \mathrm{m}, 5.4-6.3 \mu \mathrm{m})$. It has a slightly higher stria density (13-16/10 $\mu \mathrm{m}$ vs. $11-14$ in $10 \mu \mathrm{m})$, coarser pores (30-35 in $10 \mu \mathrm{m}$ vs. ca. 40 in $10 \mu \mathrm{m}$ ), slightly broader apices and a slightly more convex valve margin, particularly at the centre, a larger, more rounded central area. It also differs in the shape of the areolae, which are round or slightly transapically elongated in C. oblongata var. parva.

Ecology. The species was found on exposed moist sand near the main inlet of the $3^{\text {rd }}$ lake (Table 1) accompanied by several species in the Achnanthidium minutissimum complex, $F$. vaucheriae and other unidentified Fragilaria species, $P$. bioretii, E. minutum and $E$. cf. brevicapitatum, D. mesodon and $P$. pseudoconstruens, and occurred rarely on exposed sediment of the inlet on the western shore of the lake, and on sediment and bryophytes in two springs.

\section{Discussion}

Morphological characteristics of Cymbopleura This study of the Cymbopleura flora of the Gokyo region revealed the presence of some interesting morphological features that have not previously (or only sporadically) been reported in Cymbopleura, i.e. areas of small rounded areolae at the apices (potential apical pore fields) and internal areola occlusions (papillae sensu KrAMMER). According to Krammer (2003), Cymbopleura is distinguished from Cymbella by the absence of apical pore fields (and thus the ability to form stalked colonies) and stigmata. But in the same work (Krammer 2003), he mentions that some species, e.g. C. naviculiformis (Auersw.) Krammer and C. subcuspidata (Krammer) KRAMMER, have structures that resemble an apical pore field, although differing in structure from the pore fields in Cymbella (KRAMMER 2002).

Our specimens of $C$. americana had an area of small, more densely spaced, rounded pores at the apices, like those in C. naviculiformis (Krammer, 2003, plate 78, fig. 5), which he likened to apical pore fields. However, internal views of $C$. naviculiformis (Fig. 51) show that, although the pores are smaller, they have the same internal struts overlying the vimines, unlike pores in true apical fields (Cox 1976, plate 5, fig. 33). Furthermore, the small helictoglossae in $C$. americana and C. naviculiformis differ from the more heavily silicified, often dorsally deflected helictoglossae of Cymbella spp. (Cox 1976, plate 5, fig. 33, plate 6 , fig. 36 ).

In the other taxa from Gokyo which were observed in SEM, shortened striae extend around the apices. In most of these, i.e. C. gokyoensis, C. naviculiformis, $C$. cf venetaeformis and $C$. oblongata v. parva, the external areola openings are very similar in shape to the stria areolae over the rest of the valve face. In $C$. cf. mongolica and $C$. emoda, the apical areola openings are rounded while the stria areolae on the valve face are elongated slits and $\mathrm{x}$-shaped, respectively. Internally, the stria structure is similar throughout the valve, although the virgae are much narrower at the apices and the areola openings of the shortened striae are more closely spaced.

Another interesting feature is the presence of what KRAMmER (1982a, 2002, 2003) called 'papillae', covering the internal areola openings in $C$. cf. venetaeformis. Similar structures are known from species of Cymbella [C. cymbiformis C.Agardh and $C$. arctica (Lagerst.) A. SChMidT (KRAMMER 2002)], Krsticiella [K. ohridana Levkov (Levkov et al. 2007)], Encyonopsis, [C. descripta (Hust.) Krammer, C. cesatii (RABenh.) Krammer, $C$. cesatiformis Krammer (Krammer 1982a, 1997b)] and Placoneis [P. pseudanglica (LANGe-Bert.) E.J. Cox (Cox 2004)], but have not previously been recorded for Cymbopleura (cf. KRAMMER 2003).

Krammer's term 'papillae' is not well chosen, papilla literally meaning a nipple, in which sense it was applied by STIDOLPH (1990) for a small process projecting outward from the surface of the girdle in Cavernosa kapitiana Stidolph. ManN (1981b) discussed the internal occlusions of $C$. cymbiformis, terming them 'volate occlusions', a term he also applied to the external occlusions of Gomphonema and other Cymbella spp. KRAMMER (1982a; 34, 1982b: p. 61) also noted the internal occlusions in some Cymbella spp., referring to them as papillae (= flaps in MANN (1981b). Cox (2004) discussed MANN's use of the term volae, but also discriminated between external and the internal flap-like occlusions, noting that in Placoneis the latter were attached by small pegs and warranted recognition as a different structure, for which she coined the term tectulum. 

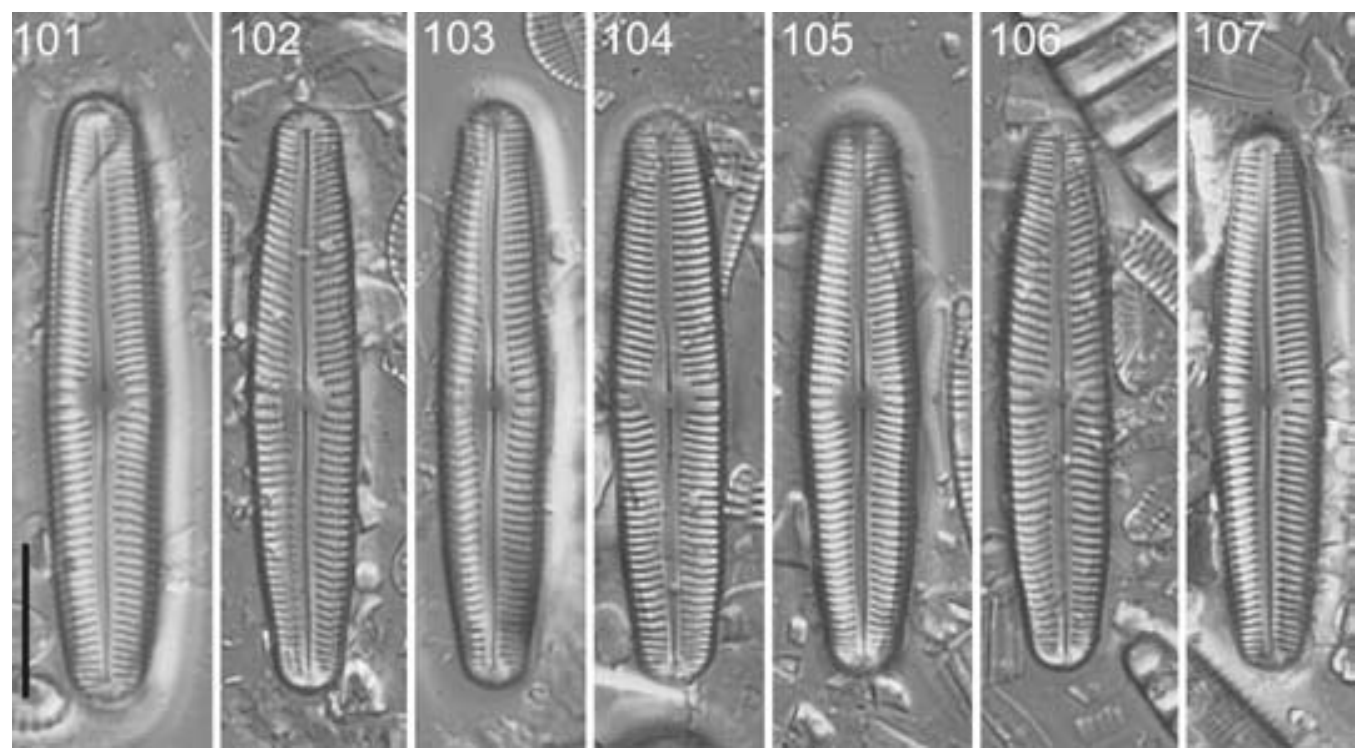

Figs 101-107. Cymbopleura emoda, LM: slide NMW.C.2009.003 G3 inlet north slope, exposed sand. Valve views. Scale bar $10 \mu \mathrm{m}$.
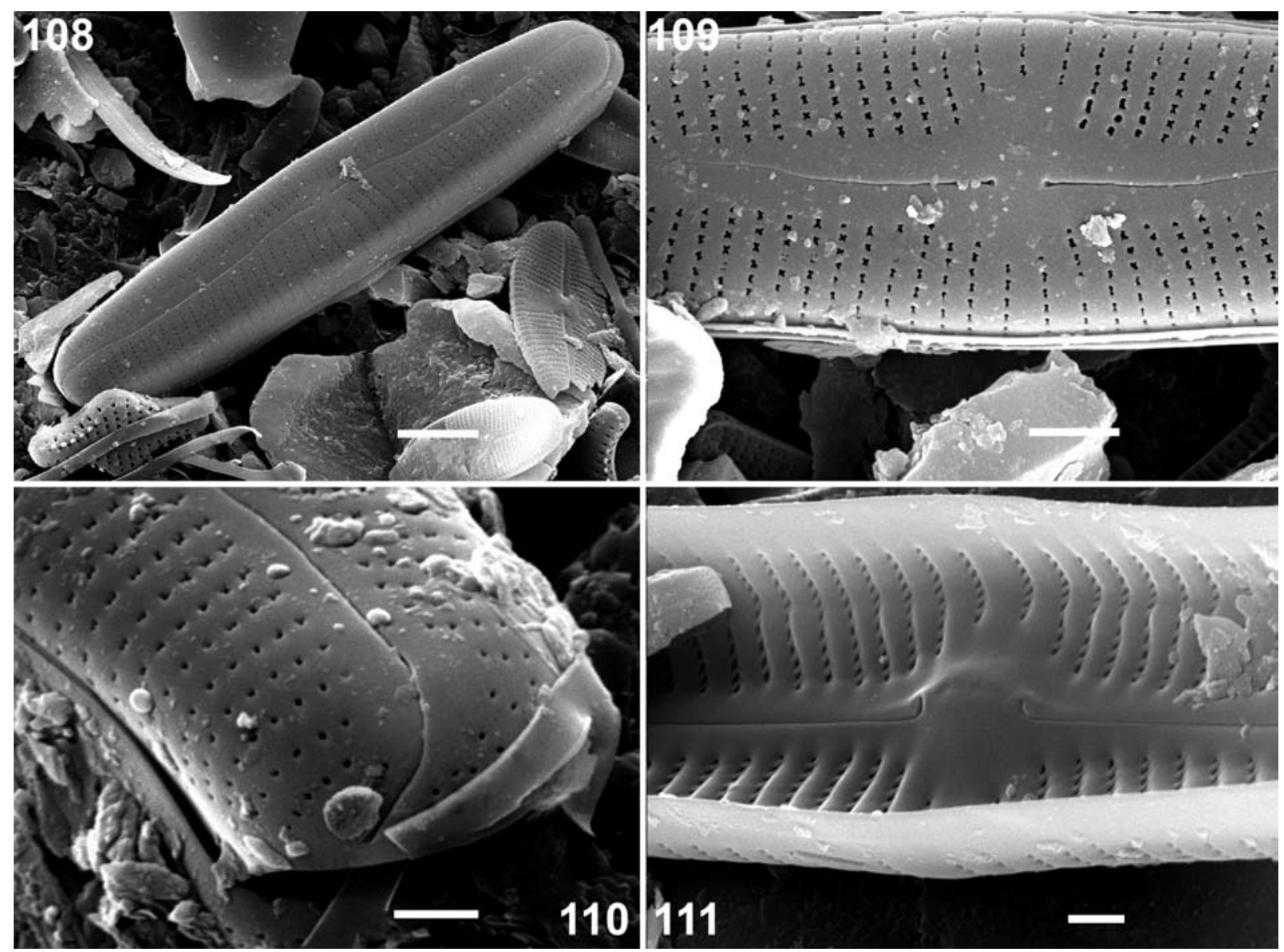

Figs 108-111. Cymbopleura emoda, SEM: stub NMW.C.2009.003 G3 inlet north slope, exposed sand. (108-110) external views, (108) whole valve, (109) valve centre with central area and $\mathrm{x}$-shaped areolae, (110) valve apex with striae extending around the apex; (111) internal view, valve centre with wide gap between central raphe endings, central nodule, broad virgae and narrow striae without struts over the vimines. Scale bar $5 \mu \mathrm{m}$ (Fig. 108); $2 \mu \mathrm{m}$ (Fig. 109); $1 \mu \mathrm{m}$ (Figs 110, 111). 
The presence of tectulum-like occlusions in several Encyonopsis species and in $C$. cf. venetaefomis raises questions about the taxonomic position of these four species. The only feature on which Encyonopsis is clearly separated from Cymbopleura is the path of the raphe. In Encyonopsis, the distal raphe fissures curve towards the ventral side, whereas in Cymbopleura they curve to the dorsal side (KRAMMER 1997a). But all four species are almost symmetrical about the apical axis making the differentiation between dorsal and ventral sides quite difficult. Ventral curvature of the distal raphe fissures in E. cesatii, E. cesatiformis and E. descripta explains their position within Encyonopsis (KRAMMER 1997b), but it is almost impossible to distinguish between dorsal and the ventral sides in $C$. cf. venetaeformis and the similar species, C. geofriedana. Krammer (2003) admitted that for the latter (given as $C$. geofriedii REICHARDT in press), dorsiventrality is "not unequivocal for all specimens" and agrees that there are links between this species and $E$. cesatiformis. If viewed in terms of primary and secondary sides of the valve (MANN 1981a), all distal raphe endings curve towards the secondary side, and the lack of dorsiventrality in $C$. cf. venetaeformis and $C$. geofriedana alone cannot be used to separate them from Encyonopsis. On the other hand, the presence of tectulum-like occlusions could indicate a relationship of all five taxa with Placoneis, which includes predominantly bilaterally symmetrical taxa, although some species show slight dorsiventrality (Cox 2003).

\section{Allocation to species}

Several Cymbopleura taxa from the Himalaya cannot be allocated to described species with $100 \%$ certainty, e.g. C. cf. gondwana, C. cf. linearis and $C$. cf. mongolica. In all cases, the observed populations have smaller valves with a higher stria density, two features that seem to be linked in diatoms. VAN DE VIJVER et al. (2006) showed the relationship between valve size and stria density, with higher stria densities always found in the smaller valves. The most likely explanation for the dimensional discrepancies between the Himalayan and type populations is that the type populations do not reflect the whole life cycle and that, possibly due to harsher climatic conditions, valves tend to be smaller. A similar relationship between environmental conditions and diatom dimensions was demonstrated for Pinnularia borealis on sub-Antarctic islands, where valves tend to become smaller when the available moisture in the habitat decreases (VAN DE VIJVER \& BEYENS 1997).

\section{Biogeographical and ecological implications}

From a biogeographical point of view the composition of the Cymbopleura flora of the Gokyo area is quite remarkable. Only two of the eleven species have a distribution that is currently restricted to the Gokyo area (C. gokyoensis and $C$. emoda). Two (C. cf. mongolica and C. nadejdae) have recently been described from Mongolia and of the remaining seven, only one (C. naviculiformis) has a cosmopolitan distribution and can be found from the Sub-Antarctic Region (VAN DE VIJVER et al. 2002) to more temperate and alpine regions in Europe, America and Asia (RumRICH et al. 2000; Krammer 2003; Li et al. 2007). Several species show a typical boreo-alpine distribution such as C. linearis and C. anglica. Cymbopleura oblongata var. parva is known from Spitsbergen but also found at higher elevations in Mongolia (Metzeltin et al. 2009). The most remarkable observation is that three species, C. gondwana, $C$. americana and $C$. cf. venetaeformis were apparently restricted to the American Continent. Cymbopleura gondwana was described from southern Chile (Rumrich et al. 2000), whereas $C$. americana was only known from one site (North Providence) in North America (KRAMmer 2003). Cymbopleura cf. venetaeformis was originally described from the Canadian Arctic (ANTONIADES et al. 2009).

The moist habitats that were richest in Cymbopleura species included the soil and sand samples collected beside the main inlet of the lake. It is possible that this high diversity is artificial and may be due to increased deposition, but submerged sediment in the inlet contained three species, while none have so far been found on other substrata in the inlet. This could indicate that their preferred habitat is fine substrata, possibly in subaerial habitats. Although a general conclusion about habitat preferences is not possible due to the rarity of the species, the analysis of submerged habitats in lakes and streams of the Gokyo area showed that only three Cymbopleura species were present and, except in the inlet of the $3^{\text {rd }}$ lake, at very low numbers. Subaerial, moist habitats might therefore be important for this genus, and diversity and species richness would be diminished if these habitats become scarcer due to a warming climate. It is therefore important to survey submerged 
substrata and adjacent, moist riparian habitats simultaneously, to assess the importance of microhabitats for different taxonomic groups.

\section{Acknowledgements}

This study was supported by WWF Nepal, who funded the investigations in the Gokyo Valley, and an EU Synthesys grant to IJ to visit the National Botanic Garden of Belgium, Meise. We would like to thank Marcel Verhaegen, National Botanic Garden of Belgium, for technical assistance with the SEM, and Jim Chimonides, The Natural History Museum, London, for the map of Nepal.

\section{References}

Agardh, C.A. (1830): Conspectus criticus diatomacearum. -1 : 1-16.

Antoniades, D., Hamilton, P.B, Douglas, M.S.V. \& Smol, J.P. (2008): Diatoms of North America. The freshwater floras of Prince Patrick, Ellef Ringnes and northern Ellesmere Islands from the Canadian Arctic Archipelago. - Iconographia Diatomologica 17: 1-649.

Antoniades, D., Hamilton, P.B., Hinz, F., Douglas, M.S.V. \& Smol, J.P. (2009): Seven new species of freshwater diatoms (Bacillariophyceae) from the Canadian Arctic Archipelago. - Nova Hedwigia 88: 57-80.

Boyer, C.S. (1927): Synopsis of North American Diatomaceae. -Proceedings of the Academy of Natural Sciences in Philadelphia 78 suppl. 2: 229-583.

Cleve, P.T. (1894): Synopsis of the Naviculoid Diatoms. - Konglige Svenska Vetenskaps-Akademiens Handlingar. Vol. 26 No. 2, Part 1. - 194 pp., P.A. Norstedt \& Söner, Stockholm.

Cox, E.J. (1976): Variation in valve structure between species of the genus Cymbella C.A.AgArdH. -Nova Hedwigia 28: 427-449.

Cox, E.J. (1999): Variation in patterns of valve morphogenesis between representatives of six biraphid diatom genera (Bacillariophyceae). Journal of Phycology 35: 1297-1312.

Cox, E.J. (2003): Placoneis Mereschkowsky (Bacillariophyta) revisited: resolution of several typification and nomenclatural problems, including the generitype. - Botanical Journal of the Linnean Society 141: 53-83.

Cox, E.J. (2004): Pore occlusions in raphid diatoms - a reassessment of their structure and terminology. - Diatom 20: 33-46.

Cox, E.J. \& Ross, R. (1981): The striae of pennate diatoms. - Proceedings of the 6th International Symposium on recent and fossil diatoms, Budapest, 1980: 267-278

Jüttner I., Krammer K., Van de Vijver B., Tuji A.,
Simkhada B., Gurung S., Sharma S., Sharma C. \& Cox E.J. (2010a): Oricymba (Cymbellales, Bacillariophyceae), a new cymbelloid genus and three new species from the Nepalese Himalaya. - Phycologia 49: 407-423.

Jüttner, I., Gurung, S., Sharma, C., Sharma, S., DE HAAn, M. \& VAN de ViJver, B. (2010b): Morphology of new taxa in the Cymbella aspera and Cymbella neocistula groups, Cymbella yakii sp. nov., and Cymbella cf. hantzschiana from the Everest National Park, Nepal. - Polish Botanical Journal 55: 73-92.

Krammer, K (1982a): Valve morphology in the genus Cymbella C.A. Agardh. - In: Helmcke, J.-G. \& Krammer, K. (eds): Micromorphology of diatom valves, Vol 11. - 299 pp., J. Cramer, Vaduz.

Krammer, K. (1982b): Observations on the Alveoli and Areolae of some Naviculaceae. - Nova Hedwigia Beihefte 73: 55-80.

Krammer, K. (1997a): Die cymbelloiden Diatomeen. Eine Monographie der weltweit bekannten Taxa. Teil. 1. Allgemeines und Encyonema Part. - Bibliotheca Diatomologica 36: 1-382.

Krammer, K. (1997b): Die cymbelloiden Diatomeen. Eine Monographie der weltweit bekannten Taxa. Teil. 2. Encyonema part., Encyonopsis and Cymbellopsis - Bibliotheca Diatomologica 37: $1-469$.

Krammer, K. (1999): Validierung von Cymbopleura nov. gen. - Iconographia Diatomologica 6: $1-292$.

Krammer, K. (2002): Cymbella. - Diatoms of Europe 3: $1-584$.

Krammer, K. (2003): Cymbopleura, Delicata, Navicymbula, Gomphocymbellopsis, Afrocymbella. - Diatoms of Europe 4: 1-530.

Krasske, G. (1949): Subfossile Diatomeen aus den Mooren Patagoniens und Feuerlands -Annales Academiae Scientiarum Fennicae, Series A.., IV Biol 14: 3-94.

Kulikovskiy, M., Lange-Bertalot, H., Witkowski, A. \& Dorofeyuk, N. (2009): Morphology and taxonomy of selected cymbelloid diatoms from a Mongolian Sphagnum ecosystem with a description of three species new to science.

- Fottea 9: 223-232.

LAGerstedt, N.G.W. (1873): Sötvattens-Diatomaceer fran Spetsbergen och Beeren Eiland. - Bihang till Kongliga Svenska Vetenskaps-Akademiens Handlingar 1/14: 1-52.

Le Cohu, R. (1996) : Ultrastructure et position systématique de deux espèces rares de Cymbella (Bacillariophyta) : Cymbella alpina Grunow et Cymbella stauroneiformis LAGERST. - Annales de Limnologie 32 : 79-87.

Levkov, Z., Krstic, S., Metzeltin, D. \& Nakov, T. (2007): Diatoms of Lake Prespa and Ohrid. 
About 500 taxa from ancient lake system. Iconographia Diatomologica 16: 1-613.

Li, Y., Gong, Z., XIE, P. \& Shen, J. (2007): Floral survey of the diatom genera Cymbella and Gomphonema (Cymbellales, Bacillariophyta) from the Jolmolungma Mountain Region of China. - Cryptogamie, Algologie 28: 209-244.

ManN, D.G. (1981a). A note on valve formation and homology in the diatom genus Cymbella. Annals of Botany 47: 267-269.

Mann, D.G. (1981b): Sieves and Flaps: Siliceous Minutiae in the pores of raphid diatoms. In: Ross, R. (Ed.) Proceedings of the sixth Symposium on Recent and Fossil diatoms, 279-301.

McNeill, J., Barrie, F.R., Burdet, H. M., Demoulin, V., Hawksworth, D. L., Marhold, K., Nicolson, D. H., Prado, J., Silva, P. C., Skog, J. E., Wiersma, J. H. \& Turland, N. J. (2007): International Code of Botanical Nomenclature (Vienna Code) adopted by the Seventeenth International Botanical Congress Vienna, Austria, July 2005. Gantner, Ruggell.

Metzeltin, D. \& Lange-Bertalot, H. (2007): Tropical Diatoms of South America II. Special remarks on biogeographic disjunction. - Iconographia Diatomologica 18: 1-877.

Metzeltin, D., Lange-Bertalot, H. \& Nergui, S. (2009): Diatoms in Mongolia. - Iconographia Diatomologica 20: 1-648.

PAtrick, R. \& Reimer, C.W. (1975): The diatoms of the United States. Monographs of the Acad. Nat. Sci. Philadelophia 2/1: Entomoneidaceae, Cymbellaceae, Gomphonemaceae, Epithemiaceae. $-213 p p$.
REICHARDT, E. (1994): Zur Diatomeenflora (Bacillariophyceae) tuffabscheidender Quellen und Bäche im Südlichen Frankenjura. - Ber. Bayer. Bot. Ges. 64: 119-133.

REICHARDT, E. (2004): Eine bemerkenswerte Diatomeenassoziation in einem Quellhabitat im Grazer Bergland, Österreich. - Iconographia Diatomologica 13: 419-479.

Rumrich, U., Lange-Bertalot, H.\& Rumrich, M. (2000): Diatomeen der Anden. Von Venezuela bis Patagonien/Tierra del Fuego. - Iconographia Diatomologica 9: 1-649.

SchmidT, A. 1875. Atlas der Diatomaceen-Kunde. Heft 5. Tafel 9-12, Leipzig, O.R. Reisland.

Stidolph, S.R. (1990): Cavernosa kapitiana, a new diatom genus and species from Kapiti Island, New Zealand. - Nova Hedwigia 50: 97-110.

VAn de ViJVer, B. \& Beyens, L. (1997): The epiphytic diatom flora of mosses from Strømness Bay area, South Georgia. - Polar Biology 17: 492501.

Van de Vijver, B., Frenot, Y. \& Beyens, L. (2002): Freshwater diatoms from Ile de la Possession (Crozet Archipelago, Subantarctica). Bibliotheca Diatomologica 46:1-412.

(C) Czech Phycological Society (2011)

Received August 15, 2010

Accepted December 6, 2010 